\title{
EQUILIBRIO DE TROCA ENTRE POTASSIO E CÁLCIO E LIXIVIAÇÃO DESTES CÁTIONS EM SOLOS COM CARGA VARIÁVEL.
}

\author{
LÚCIA HELENA GARÓFALO CHAVES
}

Orientador: Dr. TOSHIAKI KINJO

\begin{abstract}
Tese apresentada à Escola Superior de Agricultura "Luiz de Queiroz", da Universidade de São Paulo, para obtenção do título de Doutor em Agronomia. Área de Concentração: Solos $\theta$ Nutrição de Plantas.
\end{abstract}

PIRACICABA

Estado de São Paulo - Brasil

Dezembro, 1984 
.ii.

Aos meus pais

Alberto e Elvira

aos meus irmãos

Esmeralda, Dirce, Maria Angela e

Carlos Alberto

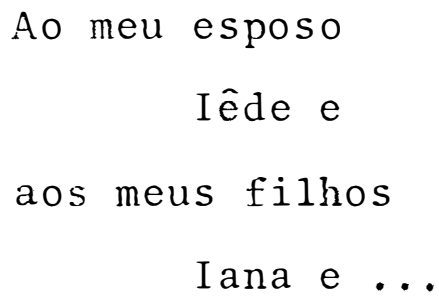

DEDICO. 


\section{AGRADECIMENTOS}

Ao Professor Dr. Toshiaki Kinjo, do Departamento de Solos, Geo logia e Fertilizantes da Escola Superior de Agricultua "Luiz de Queiroz", pela orientação segura e constante na elaboração deste trabalho.

Ao Professor Dr. Paulo Leonel Libardi do Departamento de Física e Meteorologia da Escola Superior de Agricultura "Luiz de Queiroz".

Ao Dr. Otâvio Antonio de Camargo, pesquisador científico do Instituto Agronômico de Campinas, SP.

Ao Professor Dr. Humberto de Campos do Departamento de Matemática e Estatística da Escola Superior de Agricultura "Luiz de Queiroz".

Aos têcnicos de laboratôrio, Mârio Benedito Lodovico e Vinicius Ferraz.

Às bibliotecárias e funcionários Luiz Carlos Veríssimo, Eurice Amaral Mello e Paulo Veríssimo Júnior, da Biblioteca Central da Escola Superior de Agricultura "Luiz de Queiroz".

Ao Departamento de Solos e Engenharia Rural do Centro de Ciências Agrärias, UFPB.

Ao Departamento de Solos, Geologia e Fertilizantes da Escola Superior de Agricultura "Luiz de Queiroz".

A Coordenadoria do Aperfeiçoamento de Pessoal de Nível Superior e Programa de Integração de Capacitação de Docentes (CAPES/PICD). 
INDICE

Página

RESUMO

xiii

SUMMARY

$x v i$

1. INTRODUÇÃO $\ldots \ldots \ldots \ldots \ldots \ldots \ldots \ldots \ldots \ldots$

2. REVisão de literatura $\ldots \ldots \ldots \ldots \ldots \ldots \ldots$

2.1. Densidade de carga superficial .... 4

2.2. Equilíbrio de troca catiônica entre

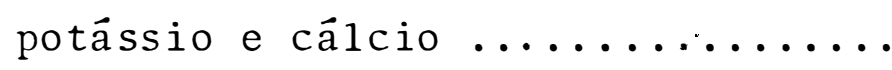

2.3. Lixiviação de câtions .............

3. MATERIAL E METODOS $\ldots \ldots \ldots \ldots \ldots \ldots$

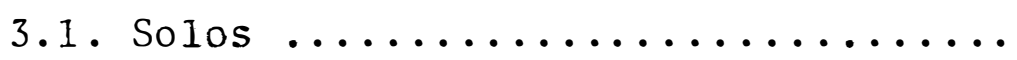

3.2. Equilíbrio de troca catiônica entre potássio e câlcio ...............

3.2.1. Solução de tratamento ......

3.2.2. Equilíbrio de troca ........

3.2.3. Extração de potāssio e câl cio trocáveis ..............

3.2.4. Determinação de potássio e

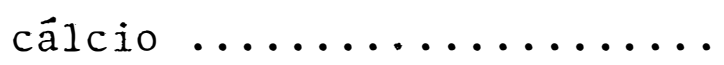

3.2.5. Cálculos ..............

3.3. Lixiviação de potássio e cálcio mais

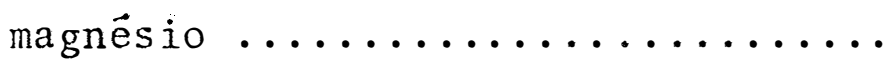


Página

3.3.1. Preparo das amostras de terra.

3.3.2. Preparo da coluna de terra....

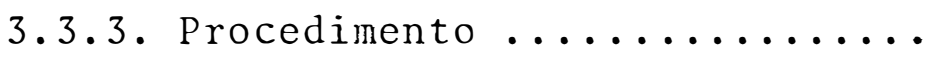

4. RESUltados E discussão $\ldots \ldots \ldots \ldots \ldots \ldots$

4.1. Densidade de carga superficial .....

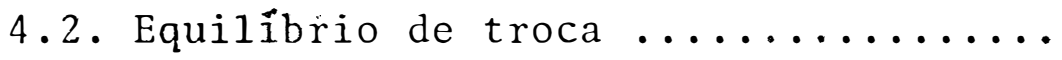

4.3. Lixiviação de potássio, cálcio mais magnësio $\ldots \ldots \ldots \ldots \ldots \ldots \ldots$

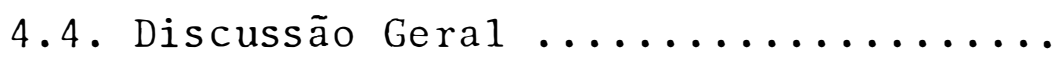

5. CONCLUSOES $\ldots \ldots \ldots \ldots \ldots \ldots \ldots \ldots \ldots$

6. Literatura CitAdA $\ldots \ldots \ldots \ldots \ldots \ldots$ 
1 - Composição mineralógica da fração argila isenta de óxidos de ferrolivres dos solos estudados ..

2 - Composição granulométrica e superfície específi

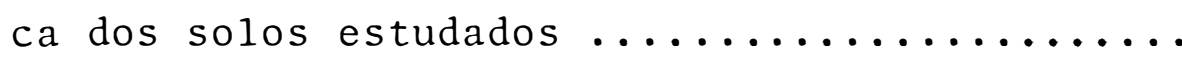

3 - Teores de carbono orgânico e de óxidos de ferro livres, valores de $\mathrm{pH}$ e capacidade de troca catiônica (CTC) $\ldots \ldots \ldots \ldots \ldots \ldots \ldots \ldots \ldots \ldots \ldots \ldots \ldots \ldots \ldots \ldots$

4 - Cátions trocâveis e acidez potencial $\left(\mathrm{H}^{+}+\mathrm{Al}^{3+}\right)$

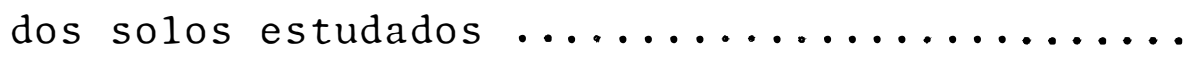

5 - Quantidade de cátions adsorvidos, valores da RPT, densidade de carga superficial ( $\Gamma)$ e coefi ciente de Gapon em relação aos tratamentos do solo. PVA-variação Laras, horizonte Ap ........

6 - Quantidade de cátions adsorvidos, valores da RPT, densidade de carga superficial (Г) e coefi ciente de Gapon, em relação aos tratamentos do solo. PVA-variação Laras, horizonte B2 ........ 
7 - Quantidade de cátions adsorvidos, valores da RPT, densidade de carga superficial ( $\Gamma)$ e coeficiente de Gapon, em relação aos tratamentos do solo. PVA-variação Piracicaba, horizonte Ap.

8 - Quantidade de cătions adsorvidos, valores da RPT, densidade de carga superficial ( $Г$ ) e coeficiente de Gapon, em relação aos tratamentos do solo. PVA-variação Piracicaba, horizonte B2.

9 - Quantidade de cátions adsorvidos, valores da RPT, densidade de carga superficial (Г) e coe ficiente de Gapon, em relação aos tratamentos

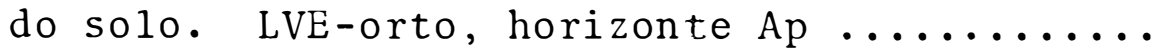

10 - Quantidade de cätions adsorvidos, valores da RPT, densidade de carga superficial ( $\Gamma$ ) e coe ficiente de Gapon, em relação aos tratamentos

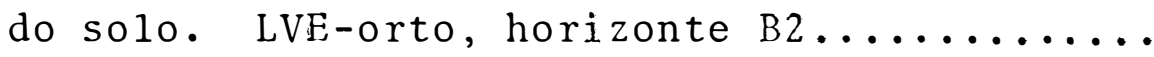

11 - Quantidade de cátions adsorvidos, valores da RPT, densidade de carga superficial ( $\Gamma$ ) e coeficiente de Gapon, em relação aos tratamentos

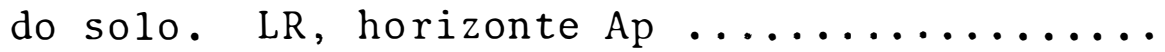


12 - Quantidade de cảtions adsorvidos, valores da RPT, densidade de carga superficial ( $\mathrm{r}$ ) e coe ficiente de Gapon em relação aos tratamentos

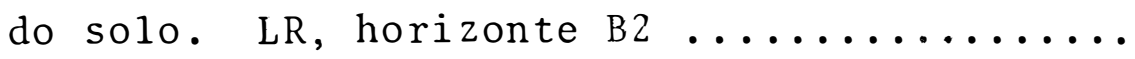

13 - Quantidade de cátions adsorvidos, valores da RPT, densidade de carga superficial ( $\Gamma$ ) e coe ficiente de Gapon em relação aos tratamentos

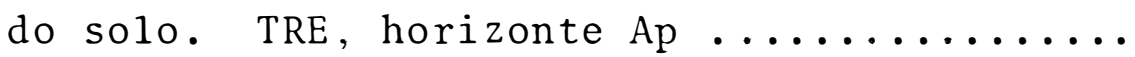

14 - Quantidade de cätions adsorvidos, valores da RPT, densidade de carga superficial ( $\Gamma$ ) e coe ficiente de Gapon em relação aos tratamentos do solo. TRE, horizonte B2 $\ldots \ldots \ldots \ldots \ldots$

15 - Regressão linear relacionando RPT (y) com RAP (x) e respectivos coeficientes de correlação (r) para os 3 níveis de $\mathrm{pH}$ da solução de equi líbrio nos solos PVA-variação Laras e PVA-variação Piracicaba $\ldots \ldots \ldots \ldots \ldots \ldots \ldots \ldots$ 
16 - Regressão linear relacionando RPT (y) com RAP (x) e respectivos coeficientes de correlação (r) para os 3 níveis de $\mathrm{pH}$ da solução de equi líbrio nos solos LVE-orto e Latossol Roxo ...

17 - Regressão linear relacionando RPT (y) com RAP (x) e respectivos coeficientes de correlação (r) para os 3 níveis de $\mathrm{pH}$ da solução de equi líbrio no solo Terra Roxa Estruturada .....

18- Quantidade de $\mathrm{Ca}^{2+}+\mathrm{Mg}^{2+}$ trocáveis e quantida de de $\mathrm{Ca}^{2+}$ adicionado à terra, para obter dois níveis de pH, antes da lixiviação, bem como quantidade de $\mathrm{Ca}^{2+}+\mathrm{Mg}^{2+} 1$ ixiviados apös o pulso de $\mathrm{K}^{+}$e quantidade de $\mathrm{Ca}^{2+}+\mathrm{Mg}^{2+} \mathrm{re}-$

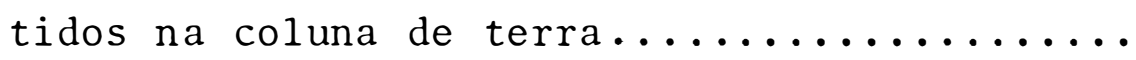

19 - Quantidade de $\mathrm{K}^{+}$trocável e adicionado a terra antes da lixiviação, quantidade $\mathrm{K}^{+}$lixivia do, após o pulso de $K$, e retido na coluna de terra bem como a razão de potâssio trocável

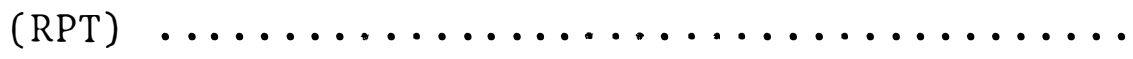


LISTA DE FIGURAS

Página

1 - Esquema e fotografia do arranjo experimental utilizado para o estudo de lixiviação .....

2 - Variação da densidade de carga superficial ( $\Gamma)$ em função do $\mathrm{pH}$ dos horizontes $\mathrm{Ap}$ e $\mathrm{B} 2$

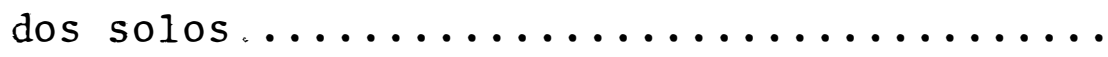

3 - Variação da razão do potássio trocáve1 (RPT) em função da razão de adsorção de potássio (RAP) para os diferentes intervalos de densi dade de carga superficial dos solos (Г) ...

4 - Relação entre a razão de potássio trocável (RPT) e a densidade de carga superficial para $\mathrm{RAP}=0,22 \ldots \ldots \ldots \ldots \ldots \ldots \ldots \ldots \ldots \ldots \ldots$

5 - Relação entre a razão de potássio trocável (RPT) e a densidade de carga superficial para RAP $=0,40 \ldots \ldots \ldots \ldots \ldots \ldots \ldots \ldots \ldots \ldots \ldots \ldots \ldots \ldots \ldots$

6 - Relação entre a razão de potássio trocável (RPT) e a densidade de carga superficial para $\mathrm{RAP}=2,00 \ldots \ldots \ldots \ldots \ldots \ldots \ldots \ldots \ldots$ 
7 - Relação entre a razão de potássio trocável (RPT) e a densidade de carga superficial pa ra $R A P=4,40 \ldots \ldots \ldots \ldots \ldots \ldots \ldots \ldots$

8 - Variação da capacidade de troca catiônica (CTC), a pH 6,0, em função da densidade de carga superficial dos solos estudados aos quatro niveis da $\operatorname{RAP} \ldots \ldots \ldots \ldots \ldots \ldots$

9 - Curvas de lixiviação de potássio e cảlcio mais magnêsio da amostra de terra do hori zonte Ap do solo PVA-variação Piracicaba. a: $\mathrm{pH} 5,8 ; \mathrm{b}: \mathrm{pH} 7,5 \ldots \ldots \ldots \ldots \ldots$

10 - Curvas de lixiviação de potássio e cálcio mais magnêsio da amostra de terra do hor zonte Ap do solo LVE-orto. a: $\mathrm{pH} \mathrm{5,2;} \mathrm{b:}$ $\mathrm{pH} \quad 6,5 \ldots \ldots \ldots \ldots \ldots \ldots \ldots \ldots \ldots \ldots \ldots$

11 - Curvas de lixiviação de potássio e cálcio mais magnêsio da amostra de terra do hor $\underline{i}$ zonte B2 do solo LVE-orto. a: pH 5,0; b: $\mathrm{pH} 6,5 \ldots \ldots \ldots \ldots \ldots \ldots \ldots \ldots \ldots$ 
. xi $\dot{i}$.

Página

12 - Variação da razão de adsorção de potāssio

(RAP) determinada em função da estimada.. 
EQUILIBRIO DE TROCA ENTRE POTÁSSIO E:CALCLIO E LIXIVIAÇĀO DESTES C.ATIONS FN SOLOS COM CARGA VARIĀVEL.

Candidata: Lücia Helena Garófalo Chaves Orientador: Prof.Dr. Toshiaki Kinjo

RESUMO

O objetivo deste trabalho foi estudar a influência da densidade de carga superficial no equilíbrio de troca entre potássio e cảlcio e na lixiviação destes câtions, em solos com carga variável.

As amostras de terra foram coletadas dos horizontes Ap e B2 dos solos Podzölico Vermelho Amarelo-variação Laras (Ustoxic Dystropept), Podzölico Vermelho Amarelo-variação Piracicaba (Aquic “ Dystropept), Latossol Vermelho Escuroorto (Typic Haplorthox), Latossol Roxo (Typic Acrustox) e Ter ra Roxa Estruturada (Oxic Rhodustalf).

O equilíbrio de troca catiônica, entre potás sio e cálcio, foi estudado utilizando-se soluções cujas razões de adsorção de potássio (RAP), isto é $(K) /(C a)^{1 / 2}$, variaram de 0,22 a $4,4(\operatorname{mmol} / 1)^{1 / 2}$. Cada nível de RAP foi combinado 
com cada um de 3 niveis de $\mathrm{pH}$, respectivamente, 4,0, 5,0 e 6,0. As amostras de terra foram lavadas 5 vezes com solução do mesmo tratamento e as quantidades de potássio e câlcio foram determinadas. A razão de potássio trocável (RPT) isto é $\mathrm{K}^{+} / \mathrm{Ca}^{2+}$, foi calculada e relacionada à RAP.

A partir dos valores destas duas razões determi nou-se os valores da constante de Gapon para cada amostra de terra. A equação da dupla camada, simplificada por BOLT (1955) foi usada para explicar o efeito da densidade de carga superfi cial sobre a adsorção de potássio em relação ao cálcio.

A lixiviação de potássio, cảlcio e magnésio,foi avaliada, em tubos de percolação, utilizando-se amostras de terra do PVA-variação Piracicaba, horizonte Ap e do LVE-orto, horizonte Ap e B2. Para cada amostra de terra foram montadas duas colunas de terra correspondendo a dois niveis de pH. Todas as colunas receberam um pulso de potássio de 0,3 meq. A RAP e a RPT foram determinadas, respectivamente a partir das quantidades de potássio e câlcio mais magnésio lixiviados e das quantidades destes cätions que permaneceram nas amostras de terra após a lixiviação.

Nas condições do experimento, a densidade de carga superficial dos solos aumenta com a elevação do pH, e a 
medida em que ela aumenta, os valores da constante de Gapon das amostras de terra diminuem, quando no equilíbrio catiôni co considera-se potảssio trocando câlcio. A variação da razão de potảssio trocâvel (RPT) é inversamente proporcional a densidade de carga superficial. O valor médio das razões en tre potâssio e câlcio mais magnésio (RAP) de cada volume de percolado coletado, correlaciona-se melhor com a razão destes câtions trocâveis (RPT) quando se leva em consideração a cons tante de Gapon. 
POTASSIUM CALCIUM EXCHANGE EQUILIBRIUM AND LEACHING IN SOILS

WITH VARIABLE CHARGE.

Candidate: Lucia Helena Gar falo Chaves

Adviser: Prof. Dr. Toshiaki Kinjo

SUMMARY

The purpose of this work was to study the influen ce of surfacè charge densịty on potassium-calciun exchange equiliffritum and leaching of the two cations in soils with variable charge.

Soil samples were collected from the Ap and B2 ho rizons of the following soils: Ustoxic Dystropept, Aquic Dystropept, Typic Haplorthox, Typic Acrustox and Oxic Rhodustalf.

For the study of potassium-calcium exchange equilibrium, four potassium adsorption ratios (PAR) varied from 0.22 to $4.40(\mathrm{mmol} / 1)^{1 / 2}$. Each level of PAR was combined with 3 levels of $\mathrm{pH}$ ranging from $\mathrm{pH} 4.0$ to $\mathrm{pH} 6.0$. Soil samples were washed 5 times with each of these solutions and the amount of potassium and calcium adsorbed were determined. Exchangeable potassium ratio (EPR) was calculated and related to the PAR values. With the values of these two ratios the Gapon's coeficients were calculated. The double layer equation, simplafied by BOLT (1955) 
was used to explain the effect of surface charge density on the adsorption of potassium in relation to calcium.

The leaching of potassium, calcium and magnesium in percolation tubes, was evaluated using soil samples collected from the Ap horizon of a Aquic Dystropept and from the Ap and B2 horizon of a Typic Haplorthox. For each soil sample two soil columns were set up corresponding to two values of $\mathrm{pH}$. The soil columns received a potassium pulse of 0.3 meq. The PAR and EPR were determined, respectively, from the amount of leached cations and the amount of the cations that stayed in the soil columns after the lixiviation.

Under the experimental conditions, the surface charge density increase with the increase of $\mathrm{pH}$, and in potassium-calcium exchange equilibrium the Gapon's coeficient of the soil samples decreasesas the surface charge density increases. The variation of EPR is inversely related to surface charge den sity. The PAR mean value has a better correlation with the EPR when the Gapon's coeficient is taken into account. 
1. INTRODUÇÃO

A solução do solo é de grande importância para a nutrição vegetal pois, é a partir dela que as raízes das plantas absorvem seus nutrientes. Por ser dificil o estudo de sua composição, determina-se pela análise dos solos os teo res absolutos dos cátions trocäveis, e a partir destes, atravês de equações, a proporção dos câtions na solução. Estes ré presentam uma fração dos câtions trocảveis e os que estão dis poníveis às plantas, uma vez que, a disponibilidade de um ele mento não está relacionado apenas ao seu teor absoluto na fra ção coloidal, mas tambẻm a força de retenção exercida pelo material coloidal e, principalmente, a presença de outros ele mentos no complexo sortivo.

Nos solos das regiões tropicais ümidas, as res postas das culturas ao potássio se relacionam mais diretamente com seus baixos teores absolutos, do que a efeitos competitivos com outros câtions. Devido a isto, as recomendações 
de adubação potássica geralmente se baseiam nos teores absolu tos do elemento. Porém, à medida em que os solos vão sendo corrigidos e adubados, as razões entre os cátions da solução (potāssio, cảlcio e magnésio), devem ser considerados, uma vez que o desequilíbrio entre eles pode causar queda na produ ção (RITCHEY, 1982). De modo geral, teores elevados de câl cio e magnésio nos solos podem diminuir a disponibilidade do potássio; assim como, elevados teores deste elemento podem induzir uma deficiência de magnésio.

Os solos intemperizados, que em geral são âcidos, apresentam, predominantemente, no complexo coloidal, minerais responsáveis pelo surgimento de cargas dependentes de pH, tais como: caulinitas, oxidos de ferro e aluminio, entre outros. Nestes solos, a medida em que se eleva o pH, surgem cargas negativas na superfície de seus colöides fazendo aumen tar a densidade de carga superficial dos mesmos.

Com o estudo do equilíbrio catiônico é possível se entender melhor o comportamento químico de um solo e portan to, uma recomendação de manejo mais adequada. A densidade de carga superficial dos colóides influi no equilíbrio catiônico dos solos, podendo-se dizer que, a medida em que ela aumenta, provavelmente, a razão entre potássio e câlcio trocâveis diminui, quando se mantém. constante a razão destes cátions na solu ção do solo. Isto se baseia no fato de que, com o aumento da 
densidade de carga superficial dos colóides ocorre adsorção pre ferencial de cátions divalentes em relação aos monovalentes o que jâ foi comprovado por vârios autores, pesquisando o equilíbrio entre sōdio e câlcio. Esse fenômeno deve tambêm influir na lixiviação de potảssio e câlcio.

Considerando-se que os solos do Estado de São Paulo contenham, predominantemente minerais com carga variảvel, que sejam, em geral, âcidos e que quando cultivados, devam rece ber calagem e adubação, supõem-se que neles ocorra adsorção pre ferencial de câlcio, em relação ao potássio a medida em que o pH aumenta. Devido à falta de informações a este respeito e sobre a influência em seus equilíbrios catiônicos, o presente tra balho tem como objetivos verificar o seguinte:

- A influência do pHl na densidade de carga super ficial dos solos;

- As variações na constante de Gapon e razão de potássio trocâvel em função da densidade de carga superficial;

- A relação entre a constante de Gapon dos solos e a razão entre o potássio e cálcio mais magnésio lixiviados. 


\subsection{Densidade de carga superficial}

O solo pode ser considerado como constituido por três fases distintas: a fase gasosa, a fase sólida e a fase líquida. A fração ativa dos solos, geralmente è formada por componentes orgânicos e inorgânicos; a líquida, pela solução do solo. Entre estas duas fases ocorre o processo de troca iônica ou especificamente, no caso de cátions, troca catiônica. Esta troca é um processo reversivel, através do qual as. partículas sôlidas do solo adsorvem cátions da fase aquosa, $1 \underline{i}$ berando ao mesmo tempo quantidades equivalentes de outros câtions, estabelecendo assim, um equilíbrio entre as duas fases (FASSBENDER, 1980). Segundo WIKLANDER (1964) a troca iônica se deve a existência de cargas elétricas nas superfícies das argilas e da matéria orgânica. 
As cargas elêtricas em colóides são classifica das como de natureza negativa e positiva, sendo as negativas responsâveis pela troca catiônica. Elas podem ter carảter permanente, quando resultam da substituição isomórfica ocorrida nos minerais de argila, e variâveis ou dependente do $\mathrm{pH}$ quando originadas pelo caráter anfótero de alguns grupos funcionais localizados na superfície de moléculas da matêria orgânica e as vezes nos óxidos e minerais de argila (FASSBENDER, 1980). A quantidade de carga por unidade de superficie, determinada através dos valores da superfície específica das partículas e da capacidade de troca catiônica (CTC), é conhecida por densidade de carga superficial e geralmente expressa em miliequivalente por centimetro quadrado (meq/ $\mathrm{cm}^{2}$ ).

Conforme WIKLANDER (1964), por causa da forma irregular das partículas de argila e a distribuição desunifor me das cargas sobre elas, a densidade de carga varia não somente com a espécie do mineral, mas tambêm na mesma partícula de argila, sendo maior em suas bordas e cavidades do que nas superfícies planas. Nos solos em geral, a densidade de carga varia com a natureza dos colóides e com o pH. As vezes, pode ser subestimada devido a presença de partículas no solo que contribuem para a superfície específica mas não para a CTC IPRATT et alii, 1962 ). 
Vários autores têm encontrado estreita correla ção entre CTC e superficie especifica, tendo em vista os coeficientes de correlação de 0,985 (MORTLAND, 1954), 0,970 (RAIJ, $1969)$ e 0,978 (GROHMANN, 1977). Segundo FASSBENDER (1980), a CTC varia entre os horizontes do solo em função do conteüdo que apresentam de argila e matēria orgânica, tendo esta eleva da superfície especifica $\left(560\right.$ a $\left.800 \mathrm{~m}^{2} / \mathrm{g}\right)$. Eliminando-se a matēria orgânica de alguns solos com horizonte B textural e B latossôlico, GROHMANN (1977), constatou uma redução de seus valores de CTC e observou também, que para uma mesma superfície específica, a CTC é maior para solos com horizonte B textural devido a natureza de sua fração argila.

Os colóides dos solos da regiäo tropical úmida do Brasil, Alfissōis, Ultissôis e Oxissóis são constituídos por caulinita, matêria orgânica, óxidos de ferro e alumínio e materiais amor fos (RAIJ, 1973) que apresentam cargas elëtricas superficiais variāveis (RAIJ e PEECH, 1972; VASCONCELLOS, 1976).

As cargas variáveis podem ser descritas pela equação de Gouy-Chapman, que, simplificada por UEHARA e GILLMAN (1980), tem a seguinte forma:

$$
\sigma_{v}=\left(\frac{2 \eta \varepsilon k T}{\pi}\right)^{1 / 2} \operatorname{sen} h 1,15 z\left(\mathrm{pH}_{\mathrm{o}}-\mathrm{pH}\right)
$$


onde:

$\sigma_{v}=$ carga superficial variāvel em esu/cm ${ }^{2}$;

$\eta$ = concentração do eletrôlito em número de ions $/ \mathrm{cm}^{3}$;

$\varepsilon=$ constante dielêtrica do solvente;

$\mathrm{k}=$ constante de Boltzman em ergs/íons grau;

$\mathrm{T}$ = temperatura absoluta;

$z$ = valência do contra-íon;

$\mathrm{pH}_{\mathrm{o}}=\mathrm{pH}$ do meio quando o potencial da superfície é zero; $\mathrm{pH}=\mathrm{pH}$ atual do meio.

Segundo a equação, a densidade de carga superfi cial varia em função do $\mathrm{pH}$ atual do meio, da concentração de eletrólito e da valência do contra-ion. 0 pH atual do meio, quando acima do $\mathrm{pH}_{\mathrm{O}}$, indica que a natureza da carga superfi cial das partículas do solo é negativa e que, quanto mais elevado o $\mathrm{pH}$ do meio, maior será a magnitude da carga negativa. Por essa razão, a incorporação de $\mathrm{Ca}(\mathrm{OH})_{2}$, o qual eleva o $\mathrm{pH}$ do meio, aumenta a capacidade de troca de cátions do solo.

0 aumento da capacidade de troca catiônica dos solos, pode ser conseguido também, pela adsorção de ânions VARBANOUA e BACHE, 1975; PRATT, 1961; ROJAS e ADAMS, 19801 e principalmente fosfato ICOLEMAN e MEHLICH, 1948; MEKARU e UEHA RA, 1972; SCHALSCHA et alii, 1972, 1974; GILLMAN e FOX, 1980). 0 ion $\mathrm{H}_{2} \mathrm{PO}_{4}^{-}$reage com as hidroxilas $(\mathrm{OH})$ das superficies dos 
minerais, por exemplo dos óxidos de Fe e Al, produzindo água e $\mathrm{HPO}_{4}^{-2}$, que fica adsorvido contribuindo assim, para o aumento do nümero de cargas negativas das superfícies. Conforme GALINDO e BINGHAM (1977), alguns solos de origem vulcânica tive ram suas cargas negativas aumentadas, em mêdia, de 0,8 meq/ /mmol de $\mathrm{P}$ adsorvido quando receberam doses crescentes de fos fato $\left(0,0053 \mathrm{M} ; 0,0212 \mathrm{M}\right.$ e $0,0400 \mathrm{M}$ de $\left.\mathrm{NaH}_{2} \mathrm{PO}_{4}\right)$.

\subsection{Equilíbrio de troca catiônica entre potássio e cálcio}

0 equilíbrio de troca entre dois cătions diferentes pode ser descrito pela seguinte equação de ação das massas:

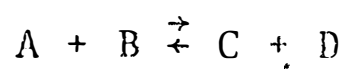

onde, $A$ e $B$ representam os reagentes e C e D os produtos. Para um par de cátion como $K$ e Ca,do complexo de troca catiônico (R), tem-se:

$$
\mathrm{RCa}+2 \mathrm{~K}^{+} \underset{\leftarrow}{\rightarrow} \mathrm{RK}+\mathrm{Ca}^{2+}
$$

sendo a equação de equilíbrio:

$$
\frac{\left(\mathrm{K}^{+}\right)_{i}}{\sqrt{\left(\mathrm{Ca}^{2+}\right)_{i}}}=\mathrm{k} \frac{\left(\mathrm{K}^{+}\right)_{\mathrm{e}}}{\sqrt{\left(\mathrm{Ca}^{2+}\right)_{\mathrm{e}}}}
$$

onde, (K) e (Ca) representam as atividades iônicas na solução interna (i) ou externa (e) em mol/l e $k \vec{e}$ a constante de equilíbrio (FASSBENDER, 1980). 
Devido a dificuldade em se determinar a atividade iônica na fase interna do equilíbrio catiônico, Gapon su pôs que esta atividade fosse igual o teor de cátions cutrocáveis.

Assim, para a troca entre K-Ca, tem-se a seguinte equação:

$$
\begin{gathered}
\mathrm{RCa}_{1 / 2}+\mathrm{K}^{+} \rightarrow \mathrm{RK}+\frac{1}{2} \mathrm{Ca}^{2+} \\
\frac{[\mathrm{RK}]_{]}}{\left[\mathrm{RCa}_{1 / 2}\right]}=\mathrm{K}_{\mathrm{G}_{\mathrm{K} / \mathrm{Ca}}} \frac{\left[\mathrm{K}^{+}\right]}{\left[\mathrm{Ca}^{2+}\right]^{1 / 2}}
\end{gathered}
$$

sendo,

$$
\begin{aligned}
\mathrm{K}_{\mathrm{G} / \mathrm{Ca}}= & \text { constante de Gapon ou coeficiente de seletividade } \\
& (\mathrm{mmol} / 1)^{-1 / 2}
\end{aligned}
$$

$\mathrm{RK} ; \mathrm{RCa}^{2+}=\mathrm{K}^{+}$e $\mathrm{Ca}^{2+}$ adsorvidos ou trocáveis, meq/100 $\mathrm{g}$

$$
\mathrm{K}^{+}, \mathrm{Ca}^{2+}=\mathrm{K}^{+} \text {e } \mathrm{Ca}^{2+} \text { em solução, mmol/1. }
$$

A equação de Gapon tem sido muito usada no estú do de solos com problemas de salinidade (ELSEEWI et alii, 1977; KINJO, 1980), porém é também empregada no estudo da adsorção preferencial de cátions por determinados minerais de argila e matéria orgânica. A seletividade catiônica nos minerais de ar gila é controlada tanto pela configuração estrutural e densida 
de de carga do mineral, quanto pelas propriedades dos cátions, como, valência, tamanho e hidratação (DOLCATER et alii, 1968).

De acordo com Schuffelen (1971) citado por MEN GEL e KIRKBY (1982), as três posições de adsorção de potässio na ilita, planar, externa e interna, apresentam diferentes coe ficientes de seletividade, sendo 2,$21 ; 102$ e infinito (mmol/ /1) ${ }^{-1 / 2}$, respectivamente. A grande preferência por potāssio na posição interna da ilita explica porque os íons $\mathrm{Na}$ e Ca não conseguem remove-1o de tal posição (BOLT et alii, 1963). Segun do Rich (1968) citado por CARSON e DIXON (1972), a ilita adsor ve potässio mais fortemente que a vermiculita e esta mais que a montmorilonita, embora tenha sido constatado que, em determi nadas condições, algumas montmorilonitas, não adsorvam potảssio seletivamente.

Em solos orgânicos têm sido constatado maior pre ferência pelo cálcio em relação ao magnésio (SALMON, 1964; HUN SAKER e PRATT, 1971 I comportamento este, idêntico ao de alguns solos calcários, porẻm ricos em matêria orgânica (GHEYI e VAN BLADEL, 1976). A retenção desses cátions, segundo BECKETT (1965), è devido à adsorção específica e que na maioria dos solos, o nümero de sítios com afinidade específica para o cấ cio ê maior que para o magnêsio. Baseado na teoria de adsor ção, a preferência dos solos pelo cálcio pode estar relaciona- 
da ao fato deste câtion apresentar menos âgua de hidratação do que o magnésio, o que o faz ser mais fortemente adsorvido pe los SOlOS (FASSBENDER, 1980 ).

A preferência pelo câlcio em relação ao magnêsio, tambëm tem sido observado ser maior em solos contendo ma teriais amorfos ou caulinita e óxidos de Fe e Al, do que naqueles contendo montmorilonita (HUNSAKER e PRATT, 1971).

Nos equilibrios heterovalentes os cätions diva lentes são adsorvidos preferencialmente, enquanto que, nos equilíbrios homovalentes o cálcio e o potássio são preferidos em relação ao magnésio e ao sỏdio, respectivamente (JENSEN $e$ BABCOCK, 1973; GALINDO e BINGHAM, 1977).

A constante de Gapon ê uma derivação empírica, que apesar de funcionar satisfatoriamente na prática para ava liar a qualidade da ägua de irrigação, segundo SPOSITO e MATTIGOD (1977), deve ser usada com certas restrições para descrever os processos de troca cationica. Isto porque, esses au tores estudando o equilibrio entre $\mathrm{Na}-\mathrm{Ca}$ observaram que a relação entre a razão de sódio trocável (RST) e razão de adsorção de sỏdio (RAS), obtida teoricamente, era indistinguível da relação empírica, apenas quando a RAS fosse igual ou menor que 40 . 
Para explicar certos fenômenos que ocorrem à superfície dos colóides que apresentam cargas elétricas, tem sido usada a equação da dupla camada que foi derivada por ERIKSSON (1952), a partir da equação diferencial de Poisson Boltzman e simplificada por BOLT (1955). Aquela equação expressa a fração da carga elétrica que é neutralizada por ín monovalente, em função das concentrações de íons mono e divalentes da solução. E apresentada da seguinte maneira:

$$
\Gamma_{1} / \Gamma=\frac{r}{\Gamma \sqrt{\beta}} \operatorname{sen}^{-1} \frac{\Gamma \sqrt{\beta}}{r+4 V_{c} \sqrt{c_{2}}}
$$

onde:

$\Gamma \quad=$ densidade de carga de uma superfície trocadora em meq $/ \mathrm{cm}^{2}$;

$\Gamma_{1} / \Gamma=$ fração da carga superficial neutralizada por um cätion monovalente;

$r=$ "razão reduzida" ou $C_{1} /\left(C_{2}\right)^{1 / 2},(\operatorname{mol} / 1)^{1 / 2}$, onde $C_{1}$ e $C_{2}$ são concentrações molares dos câtions mono e divalente, respectivamente;

$B=1,06 \times 10^{15} \mathrm{~cm} \mathrm{~mol} / \mathrm{meq}^{2}$ à $25^{\circ} \mathrm{C}$.

$\mathrm{Vc}=1,0$.

Uma vantagem da equação da dupla camada em rela ção às equações de Kerr e Vanselow, que requerem coeficientes empíricos, è que ela permite o cálculo da distribuição iônica através. de parâmetros, tais como CTC, superfície es- 
pecifica e concentração de solutos da concentração IBOHN et alie, 19791.

A equação da dupla camada, segundo vários auto res, descreve adequadamente o equilíbrio de troca cationica, quando os valores de densidade de carga superficial são corrigidos por um fator. BOLT (1955) encontrou um fator 1,2 para o equilibrio Na-Ca em ilita; BOWER (1959) um fator de 1,4 para o mesmo par de cátions em quatro solos e duas argilas e KINJO (1980) da mesma maneira, encontrou para os solos Podzólico Vermelho Amarelo variação Laras e Piracicaba, Latossol Roxo, Terra Roxa Estruturada e Latosso1 Verme1ho Escuro-orto, os fatores 1,$5 ; 2,0 ; 2,5$ e 3,0 . O valor dos fatores de correção $\vec{e}$ influenciado, provavelmente, pela natureza específica das cargas elétricas negativas e pelos valores subestimados de densidade de carga superficial dos solos, por causa de mate riais que contribuem para a superfície especifica destes e não para a capacidade de troca cationica (PRATT et alii,1962).

o efeito do pH no equilíbrio de troca catiônica entre sódio e cálcio foi analisada por PRATT et alii (1962) atravës da equação da dupla camada. -s autores observaram que, em solos orgânicos e com argila amorfa, a mudança da relação $\mathrm{Na} / \mathrm{Ca}$ da fase adsorvida ocorreu em função do $\mathrm{pH}$ da solução de equilibrio e que o efeito do pH estava relacionado à variação da densidade de carga superficial do solo. A refe 
xida relação diminuiu com a elevação da densidade de carga sú perficial, mostrando que a adsorção preferencial do câlcio,em relação ao sôdio, aumentou com a densidade de carga. 0 mesmo fenômeno foi observado por GALINDO e BINGHAM (1977) em solos de cinza vulcânica e por KINJO (1980), em solos da região tro pical ümida.

Tambëm em solos de origem vulcânica, foi obse $\underline{r}$ vado uma diminuição na relação $\mathrm{K} / \mathrm{Ca}$ da fase adsorvida; à medi da em que o pH, CTC e densidade de carga dos solos aumentaram, comprovando a adsorção preferencial do câlcio em relação ao potâssio (SCHALSCHA et alii, 1975).

De modo geral, o aumento da densidade de carga superficial favorece a adsorção de cătions divalentes sobre os monovalentes $\mid B O L T, 1955)$.

2.3. Lixiviação de cátions.

O movimento descendente da ägua livre em um perfil, causando perda de sais solúveis, é conhecido como pro cesso de lixiviação. Este processo pode exaurir os solos de certos nutrientes, sendo que a perda destes é determinada pela sua interação com o solo e por fatores climäticos (BRADY, 1979). Em regiões onde é elevada a percolação da âgua, o potencial de lixiviação é igualmente elevado. Nos solos tropi- 
cais da Africa Ocidental, as perdas são proporcionais à quan tidade anual de chuva. Na Colômbia, em solos Andepts, sob elevada precipitação, foram detectados elevadas perdas de ni trato, câlcio e magnésio (Sanches, 1976, citado por ESPINOZA e REIS, 19821. Aumento na lixiviação de fósforo, potāssio, cálcio e magnésio, também foi observado estar de acordo com o aumento do volume de água percolado (HAVERAAEN, 1978; ZAWARTKA, 1978; ESPINOZA e. REIS, 19821.

As propriedades do solo influenciam a perda de nutrientes. De modo geral, solos arenosos possibilitam maiores perdas de nutrientes de que as argilas, não só por apresentarem maior percolação como também pela sua menor capacidade de adsorção de nutrientes. Segundo MORAIS et alii 119761, as cargas elétricas dos solos são responsâveis pelas propriedades de troca ionica, que, por sua vez, determinam a movimentação dos nutrientes dentro do perfil do solo. RAIJ $e$ CAMARGO (1974), esclarecem que a lixiviação de câtions é decorrência, em parte, de alguns ânions não serem retidos pe los solos. Assim, no caso da aplicação de KCl por exemplo., deve haver lixiviação de cátions que acompanham o ânion cloreto em seu movimento através do solo.

Vârios trabalhos estudando o efeito dos ânions sobre a adsorção de potássio pelos solos têm constatado que 
o ânion acompanhante do elemento influi na sua perda e que es ta aumenta na seguinte ordem $\mathrm{KH}_{2} \mathrm{PO}_{4}$ ou $\mathrm{K}_{3} \mathrm{PO}_{4}<\mathrm{K}_{2} \mathrm{SO}_{4}<\mathrm{KCl}$ IAYRES e HAGIHARA, 1953; WANN e UEHARA, 1978; DEFELI PO e BRAGA, 19831 .

A aplicação do íon fosfato no solo e sua adsor . ção pelos colóides aumenta a capacidade de troca catiônica do solo. Baseado nisto foi observado que a lixiviação de KCl po deria ser reduzida pela aplicação no solo de $\left(\mathrm{NH}_{4}\right)_{2} \mathrm{HPO}_{4}$ (AY RES e HAGIHARA, 19531 e que a medida em que se elevava o nível de fósforo colocado no solo, as perdas de potássio dimi nuiam (WANN e UEHARA, 1978 ).

Sistemas com elevada densidade de carga e, por tanto, grande capacidade de troca, como as montmorilonitas, re têm em forma preferencial os íons divalentes. Assim, tem-se observado que ao diminuir a capacidade de troca cationica de diferentes minerais, diminui tambëm a relação dos ions $\mathrm{Ca} / \mathrm{K}$ retidos (BORNEMISZA, 1982). Jâ os solos das regiões tropicais ricos em minerais de argila do tipo caulinita (1:1), apresentam execessiva perda de potássio pelo fato destes minerais não adsorverem potässio seletivamente (MENGEL e KIRKBY,1982).

A lixiviação de cátions, particularmente do potássio, ê influenciada pela capacidade de troca catiônica a qual está relacionada com o pH do solo e com os teores de cál 
cio e magnésio (RAIJ e CAMARgo, 1974). SOUzA et alii 11979), indicaram que, sendo a capacidade de troca catiônica efetiva, e as cargas negativas dos solos cerrados, baixas, é de se esperar que haja perdas de potássio por lixiviação caso não se faça um manejo adequado da adubação potássica. A diminuição do pH dos solos causa uma redução da razão entre cátions divalen tes e monovalentes adsorvidos $(\mathrm{Ca} / \mathrm{k})$. Isto concorda com as de ficiências de câlcio observadas nos Oxissỏis do Brasil Central (Soares et alii 1975, citados por BORNEMISZA, 1982).

A respeito da influência da calagem sobre a $1 \underline{i}$ xiviação de potássio em solos tropicais, é comum encontrar cí tações a respeito de que os solos corrigides com calcário retêm mais potássio do que solos ácidos, ou seja, diminui a lixiviação do elemento para os horizontes mais profundos IKAMPRATH e FOY, 1973; WIKLANDER, 19601. Segundo YORK et alii 119531 isto ocorre devido ao fenômeno da fixação do potāssio ou então, porque o elemento troca melhor com o câlcio do que com o hidrogênio adsorvido aos colóides minerais (MOHR, 1960).

Em cinco solos do Estado de São Paulo, foi cons tado que a perda de potássio está inversamente relacionada com os teores trocäveis de cálcio e magnësio (RAIJ e CAMARGO,1974). Em Oxissóis e Ultissóis do sul do Brasil e em solos do Triângulo Mineiro, tambëm foi observado a diminuição da quantidade 
de potássio na solução do solo devido o emprego de calagem IGOEDERT et alii, 1975; DEFELIPO e BRAGA, 1983). De acordo com QUAGGIO et alii (1982), a redução das perdas de potássio devi do a calagem em um Latossolo Roxo distrófico,está associada com o aumento da retenção de bases provocada pela liberação de cargas negativas dependentes do $\mathrm{pH}$.

BRAUNER e GARCEZ (1982) analisando o efeito de doses crescentes de $\mathrm{CaCO}_{3}$ em solos do Rio Grande do Sul, Planossolo, Podzólico Vermelho Amarelo e Brunizem constataram que nos dois primeiros solos houve diminuição na lixiviação de po tássio para doses até 2,16 e 7 meq $\mathrm{CaCO}_{3} / 100 \mathrm{~g}$, respectivamen te. Porẻm, no Brunizem, à medida que as doses de $\mathrm{CaCO}_{3}$ foram aumentadas, as perdas de potássio também aumentaram, concor dando com o que ocorreu em solos da Nova Zelândia IEDMEADES, 19821. Esta mesma observação foi feita por muitos outros autores supondo, inclusive, que o cálcio e magnësio aceleram o processo de lixiviação de potässio (HOSSNER e DOLL, 1970). Con forme BITTENCOURT e SAKAI (1975), algumas vezes a adição de calcário pode provocar uma mobilização do potássio, mesmo de formas não trocáveis, o qual passa a ser lixiviado com maior facilidade. Segundo REEVE e SUMNER (1972), a calagem causa perda de potássio só enquanto estiver ocorrendo a saturação do solo com cálcio sem aumento da capacidade de troca catiônica dependente de $\mathrm{pH}$. 
Ao conträrio do que foi comentado, HAVERAAEN 11978); RITCHEY et alii (1981) e ROSOLEM e MACHADO (1984), Ob servaram em seus trabalhos que a calagem não teve nenhum efei to sobre a lixiviação de potássio. 
Para que fosse alcançado os objetivos propostos estudou-se o equilíbrio de troca catiônica entre potássio e câlcio e a lixiviação destes em relação a densidade de carga elétrica superficial.

\subsection{Solos}

Os solos utilizados no presente trabalho ocorrem no Município de Piracicaba, Estado de São Paulo. Segundo às classificações da Comissão de Solos do CNPEA (BRASIL, 1960) e do sistema americano de classificação (E.U.A., 1975), foram classificados como Podzölico Vermelho Amarelo-variação Laras (Ustoxic Dystropept), Podzölico Vermelho Amarelo-variação Pira cicaba (Aquic Dystropept), Latossol Vermelho Escuro-orto (Typic Haplorthox), Latossol Roxo (Typic Haplustox) e Terra Roxa Estruturada (Oxic Rhodustalf). A composição mineralögica da fra 
ção argila estā apresentada na Tabela 1 e as características físicas e químicas dos solos nas Tabelas 2,3 e 4 .

As amostras de terra foram coletadas dos hori zontes Ap e B2 de cada solo, secas ao ar, destorroadas e em se guida passadas por uma peneira com malha de $2 \mathrm{~mm}$.

\subsection{Equilíbrio de troca catiônica entre potāssio e cālcio}

\subsubsection{Solução de tratamento}

Para analisar o comportamento do potāssio nos so los em função de diferentes nỉveis de Razão de Adsorção de Potássio (RAP) e pH foram preparadas soluções de tratamento conten do potássio e cálcio em diferentes proporções. Estas soluções deveriam apresentar os seguintes valores de RAP: 0,2;0,4;2,0 e 4,0. Cada um deles foi combinado com os seguintes níveis de pH: 4,$0 ; 5,0$ e 6,0 . As soluções de tratamento foram preparadas man tendo-se a concentração de cálcio constante (5 mmoles/1) e a de potássio, variâvel $(0,45 ; 0,9 ; 4,5$ e 9,0 mmoles/1), tendo o seu pH sido ajustado com hidróxido de potássio, ou ácido clorídrico $0,1 \mathrm{~N}$. Após o ajuste, foram determinadas as concentrações. de potássio e de cálcio das soluções de tratamento e seus valores de RAP, os quais variaram de 0,22 a 4,64 , como mostram as Tabelas de nümero 5 ao 14 . 


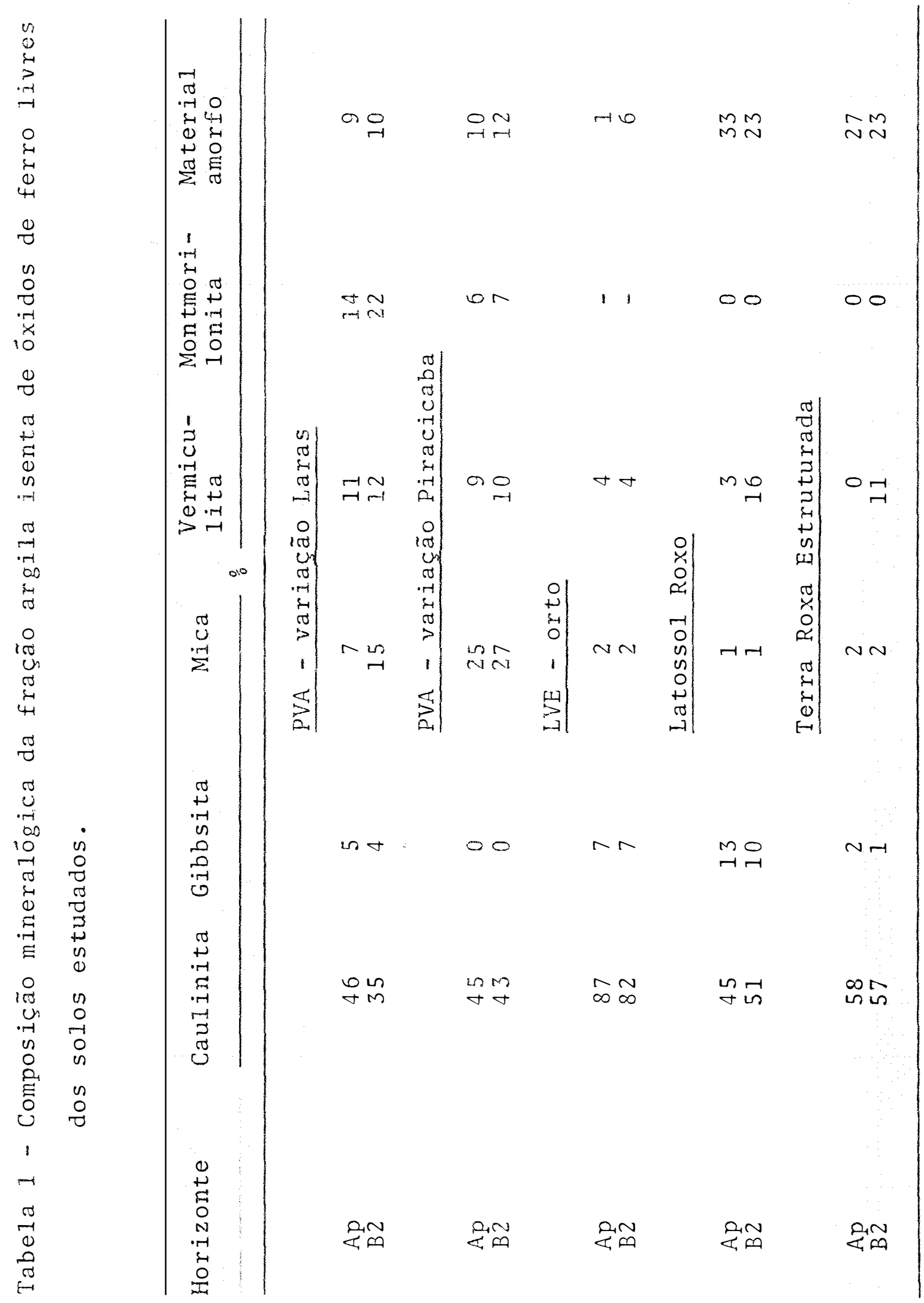


Tabela 2 - Composição granulomêtrica e superfície específica dos solos estudados.

\begin{tabular}{|c|c|c|c|c|}
\hline Horizonte & Areia & $\begin{array}{c}\text { Silte } \\
\\
\end{array}$ & Argila & $\begin{array}{c}\text { Superficie es } \\
\text { pecífica } \\
\mathrm{m}^{2} / \mathrm{g}\end{array}$ \\
\hline
\end{tabular}

\begin{tabular}{|c|c|c|c|c|}
\hline \multicolumn{5}{|c|}{$\underline{\text { PVA-variação Laras }}$} \\
\hline \multirow[t]{2}{*}{$\begin{array}{l}\text { Ap } \\
\text { B2 }\end{array}$} & $\begin{array}{l}83,0 \\
72,0\end{array}$ & $\begin{array}{l}6,0 \\
9,0\end{array}$ & $\begin{array}{l}11,0 \\
19,0\end{array}$ & $\begin{array}{l}23,877 \\
45,323\end{array}$ \\
\hline & \multicolumn{4}{|c|}{$\underline{\text { PVA-variação Piracicaba }}$} \\
\hline \multirow[t]{2}{*}{$\begin{array}{l}\text { Ap } \\
\text { B2 }\end{array}$} & $\begin{array}{l}50,0 \\
20,0\end{array}$ & $\begin{array}{l}18,0 \\
24,0\end{array}$ & $\begin{array}{l}32,0 \\
56,0\end{array}$ & $\begin{array}{r}84,153 \\
133,073\end{array}$ \\
\hline & & LVE-orto & & \\
\hline \multirow[t]{2}{*}{$\begin{array}{l}\text { Ap } \\
\text { B2 }\end{array}$} & $\begin{array}{r}26,0 \\
7,0\end{array}$ & $\begin{array}{l}6,0 \\
5,0\end{array}$ & $\begin{array}{l}68,0 \\
88,0\end{array}$ & $\begin{array}{l}65,432 \\
87,255\end{array}$ \\
\hline & & \multicolumn{3}{|c|}{ Latossol Roxo } \\
\hline \multirow[t]{2}{*}{$\begin{array}{l}\text { Ap } \\
\text { B2 }\end{array}$} & $\begin{array}{l}23,0 \\
12,8\end{array}$ & $\begin{array}{l}18,0 \\
16,0\end{array}$ & $\begin{array}{l}59,0 \\
71,2\end{array}$ & $\begin{array}{l}72,356 \\
63,838\end{array}$ \\
\hline & & Terra Roxa & a Estruturada. & \\
\hline $\begin{array}{l}\text { Ap } \\
\text { B2 }\end{array}$ & $\begin{array}{l}31,0 \\
17,0\end{array}$ & $\begin{array}{l}20,0 \\
10,0\end{array}$ & $\begin{array}{l}49,0 \\
73,0\end{array}$ & $\begin{array}{l}76,860 \\
82,907\end{array}$ \\
\hline
\end{tabular}

Obs.: As anâlises granulomëtricas foram feitas pelo mëtodo de Bouyoucos (1951).

As determinações de superfície específica foram feitas pelo método de CIHACEK e BREMNER (1979). 


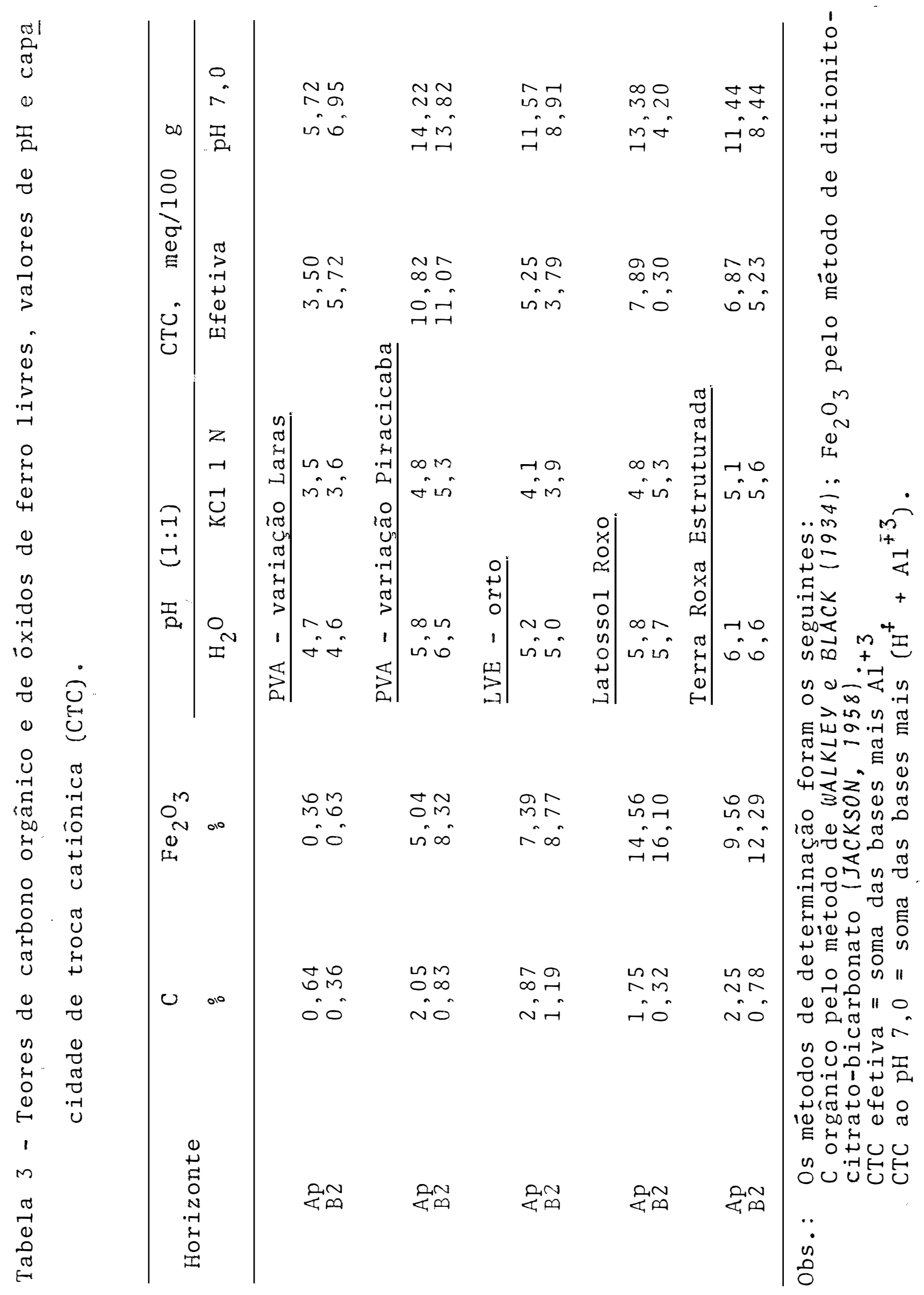




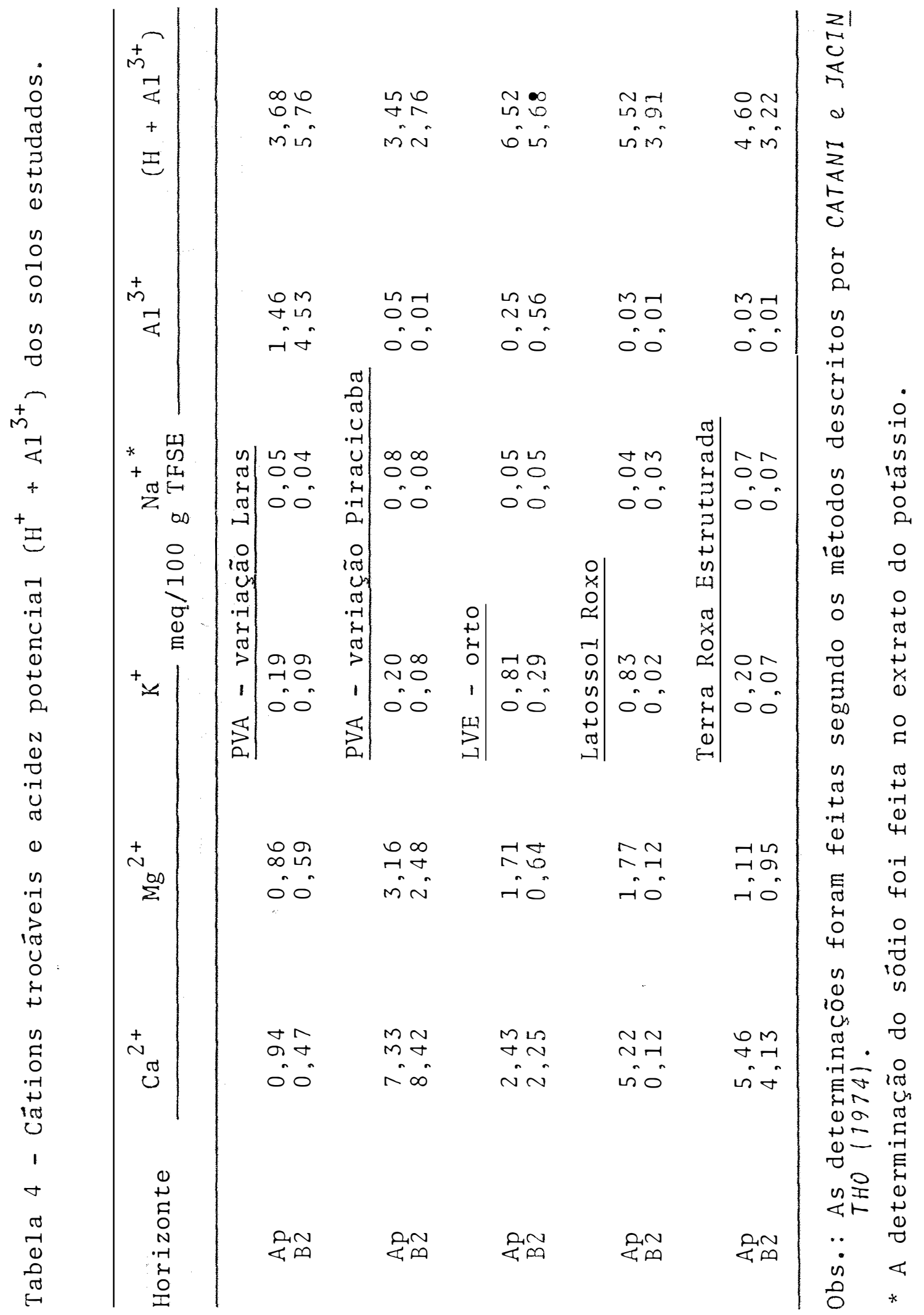




\subsubsection{Equilíbrio de troca}

Primeiramente pesaran-se os tubos de centrífuga de $50 \mathrm{ml}$ para obtenção de suas taras; em seguida 4 gramas de terra fina seca ao ar e $40 \mathrm{ml}$ da solução de tratamento foram colocados num tubo já pesado. Após agitação por 15 minutos em agitador horizontal, foi verificado o pH da suspensão sendo este ajustado ao valor desejado, quando necessärio, adicio nando solução de hidróxido de potássio e/ou äcido clorídrico a $0,1 \mathrm{~N}$. Constatado o ajuste do $\mathrm{pH}$ da suspensão, esta foi cen trifugada, descartando-se, depois, a solução sobrenadante. Es ta operação foi repetida cinco vezes, uma vez observado por VASCONCELLOS (1976), ser o bastante para que as concentrações dos cátions na solução de equilíbrio fossem 'idênticas às das soluções usadas como tratamento. Na quinta lavagem da terra com a solução de tratamento, o pH da suspensão foi medido e considerado como pH de equilíbrio. Após eliminação da solu ção sobrenadante, o tubo de centrífuga foi pesado a fim de sé obter o peso da solução que permaneceu no tubo juntamente com a massa de terra. O volume desta solução foi calculada consi derando a densidade da solução como $1 \mathrm{~g} / \mathrm{cm}^{3}$.

3.2.3. Extração de potảssio e cảlcio trocāveis

A extração do potássio e cálcio foi feita no mesmo tubo, com $40 \mathrm{ml}$ de äcido nítrico a 0,05 N. Após agita- 
ção por 15 minutos e centrifugação, uma alíquota de $30 \mathrm{ml}$ de extrato foi transferida para frasco de $100 \mathrm{ml}$ e neutralizada com hidróxido de amônia $(1+3)$. A neutralidade foi indicada pelo Vermelho de Metila 0,1:. A solução foi fervida por cin co minutos, esfriada e transferida para balão volumétrico de $50 \mathrm{ml}$, completando-se o volume com ägua destilada.

\subsubsection{Determinação de potássio e câlcio}

o potássio foi determinado por fotometria de chama sendo o fotômetro de chama aferido com água destilada a zero e solução padrão de potássio a $0,0005 \mathrm{M}$ a 100. As determinações de câlcio foram feitas pelo método da quelatometria utilizando-se EDTA $0,01 \mathrm{M}$.

As quantidades desses cătions, retidos na terra na forma de trocävel, foram calculadas pela diferença entre as quantidades encontradas no extrato e aquelas encontradas na solução que permaneceu junto à massa de terra, que foram esti madas atravês do volume dessa solução e da concentração da só lução de tratamento.

\subsubsection{Cálculos}

A soma do potássio e cálcio retidos na amostra de terra foi considerada como sendo sua capacidade de troca de cátions efetiva. 
A Razão de Potảssio Trocảvel (RPT) de acordo com a equação de Gapon, foi calculada a partir das quantida des de potässio e câlcio trocáveis, expressas em meq/100 g TFSE.

A constante de Gapon $\left(\mathrm{K}_{\mathrm{G}}\right)$ que representa o coe ficiente de seletividade de potássio na troca K-Ca, foi deter minado pela equação:

$K_{G K-C a}=\frac{K \text { adsorvido }}{C a \text { adsorvido }} \div \frac{K \text { em solução }}{(\text { Ca em solução })^{1 / 2}}$

sendo os câtions adsorvidos dados em meq/100 g TFSE e os em so 1 ução em "mmol/l.

A densidade de carga superficial (meq/ $\mathrm{cm}^{2}$ ) foi calculada a partir dos valores da capacidade de troca cationica (meq/100 g) e da superfície especifica $\left(\mathrm{m}^{2} / \mathrm{g}\right)$ de cada amostra de terra.

3.3. Lixiviação de potâssio e câlcio mais magnêsio

3.3.1. Preparo das amostras de terra

As amostras de terra utilizadas foram dos horizontes Ap e B2 do Latossol Vermelho Escuro-orto e do horizonte Ap do Podzólico Vermelho Amarelo-variação Piracicaba. Estas 
foram escolhidas por apresentarem valores distintos de densidade de car ga superficiale valores de pH tais, que com a incorporação de hidróxido de cảlcio, $\mathrm{Ca}(\mathrm{OH})_{2}$, fosse possivel uma elevação sig nificativa dos mesmos e, consequentemente, da densidade de carga superficial.

As amostras de terra do Latossol Vermelho Escu ro-orto,horizontes Ap e B2 e Podzólico Vermelho Amarelo-varia ção Piracicaba, horizonte Ap, foram incubados com $\mathrm{Ca}(\mathrm{OH})_{2}$ durante 8 dias, tempo suficiente para elevar seus pH à 6,$5 ; 6,5$ e 7,5 , respectivamente.

A lixiviação do potâssio e cảlcio mais magnê sio foi analisada tanto nas amostras de terra que não receberam $\mathrm{Ca}(\mathrm{OH})_{2}$ como naquelas que receberam, portanto, foram montadas ao todo, seis colunas de terra.

\subsubsection{Preparo da coluna de terra}

O estudo da lixiviação de potảssio e cảlcio mais magnêsio foi conduzido em tubo de percolação de $2,6 \mathrm{~cm}$ de diâmetro.

Na base do tubo de percolação, para impedir a perda de terra e facilitar a percolação, foram colocados em se quência, uma tela de nylon, duas telas de bidin, uma camada de 
de areia com espessura em torno de $0,5 \mathrm{~cm}$ e mais duas telas de bidin sobre a areia. Em seguida, $100 \mathrm{~g}$ de terra fina seca ao ar, passadas em peneiras de $1 \mathrm{~mm}$, foram acondicionados lenta mente, com a ajuda de um funil de haste longa, de modo a se conseguir a menor variação de sua densidade, ou seja, evitar a separação das partículas da terra por tamanho.

Depois de pronta, a coluna de terra foi saturada com água destilada com a finalidade de expulsar os gases, sendo umedecida a partir da base.

Constatada a saturação total da terra, o tubo de percolação foi preso a um suporte nio qual tambēm se encon trava um frasco de Mariotte com capacidade de $1000 \mathrm{~m} 1$. Este dispositivo de pressão constante foi conectado, atravēs de tubo de lätex, à superfície da coluna de tal maneira a manter una carga hidrâulica constante, de $3 \mathrm{~cm}$ de altura, sobre a terra (Figura 1).

\subsubsection{Procedimento}

No início do processo de lixiviação, foi deixado passar através da terra apenas água destilada com intuito de retirar os cátions solúveis do solo. A partir do momento em que se obteve concentrações constantes de potássio e cảlcio 


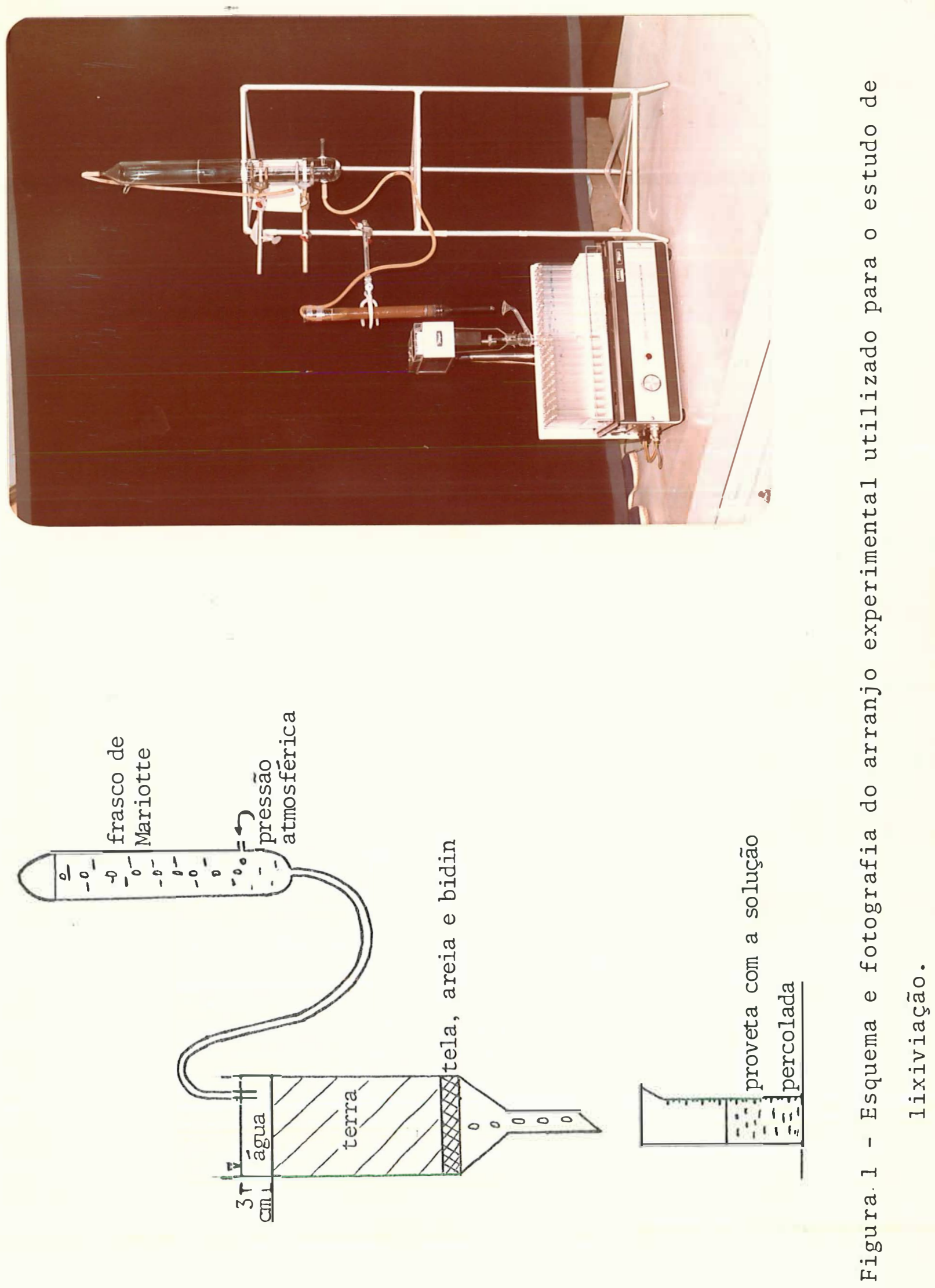


mais magnêsio na solução percolada, o fornecimento de āgua à coluna de terra foi interrompida.

Retirou-se a água da superfície da terra e colocou-se o pulso, isto ê, dois milizitros de cloreto de potás sio $0,15 \mathrm{~N}\left(0,3\right.$ meq $\left.\mathrm{K}^{+} / 100 \mathrm{~g}\right)$. Em seguida continuou-se com o fornecimento de ăgua destilada pela superfície do solo.

A solução percolada foi coletada automaticamen te atravês de um coletor de amostras da Toyo Seisakusho Co. Ltd., modelo SF160 (Figura 1) , permitindo assima obtenção de amostras de mesmo volume em intervalos de tempo pra ticamente constantes.

Nestas amostras foram determinados o potảssio por fotometria de chama e cálcio mais magnésio por quelatometria, utilizando o EDTA.

A coleta das amostras foi interrompida quando a concentração dos elementos nestas se tornou praticamente constantes. 
4. RESULTADOS E DISCUSSÃO

\subsection{Densidade de carga superficial}

A variação da densidade de carga superficial em função do pH para uma RAP igual a 4,0, nos horizontes Ap e B2 dos solos estudados, é apresentada na Figura 2 .

Segundo a equação de Gouy-Chapman (UEHARA e GIL LMAN, 1980) os valores de densidade de carga aumentaram com o $\mathrm{pH}$, com exceção do horizonte B2 do LR, a pH 6,0. Este teve sua densidade de carga superficial diminuida, o que não foi possivel explicar com base na literatura consultada.

As densidades de carga variaram de $0,18 \times 10^{-7}$ a $0,85 \times 10^{-7} ; 0,24 \times 10^{-7}$ a $1,06 \times 10^{-7}$ e de $0,23 \times 10^{-7}$ a $1,17 x$ $x 10^{-7} \mathrm{meq} / \mathrm{cm}^{2}$, nas faixas de $\mathrm{pH} 4,0 ; 5,0$ e 6,0 respectivamen te. Estas variações, numa mesma faixa de $\mathrm{pH}$, ocorrem tanto pe 1o fato dos solos possuièrem diferentes teores e natureza de matéria orgâa 


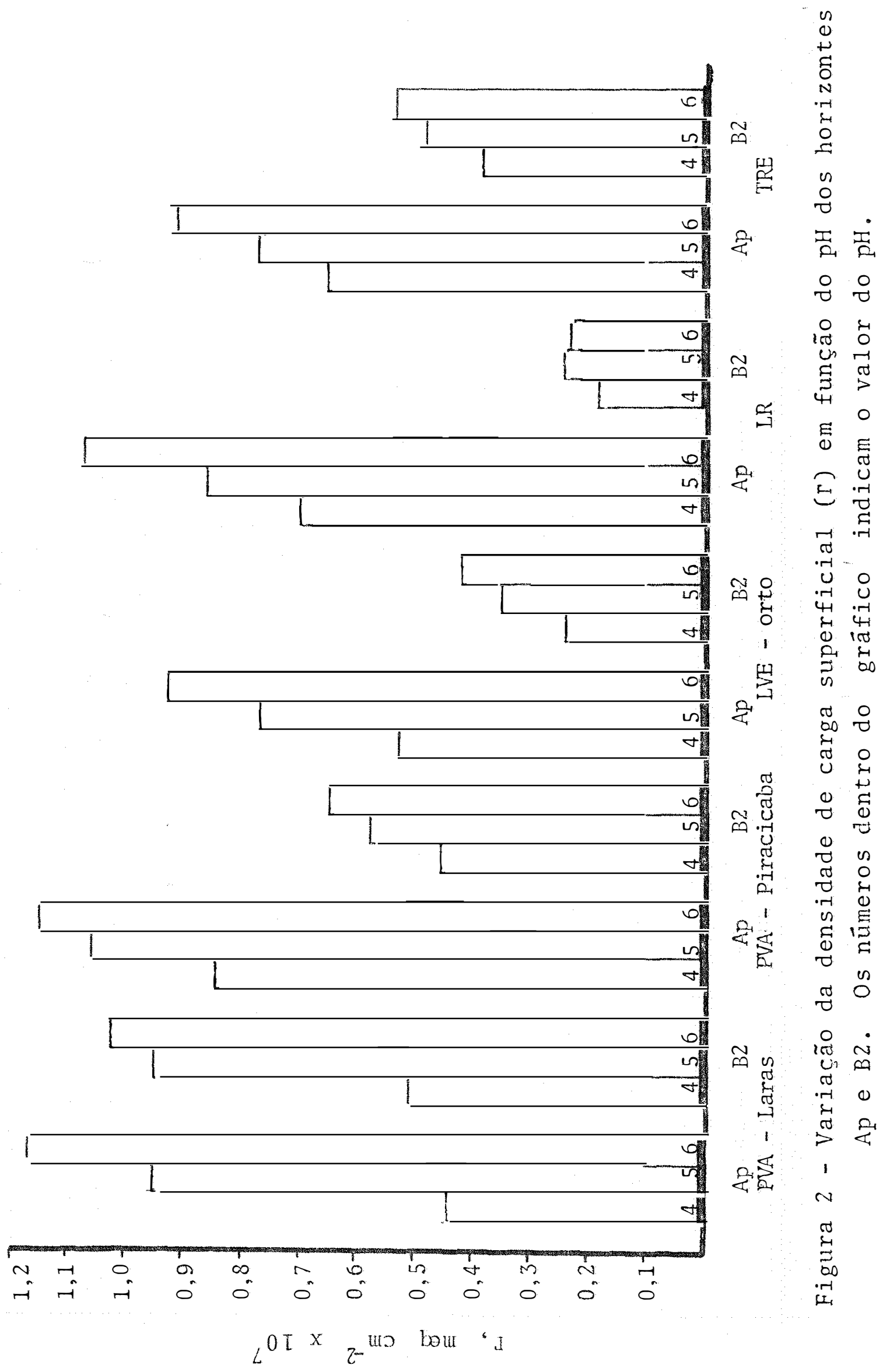


nica e de fração argila (Tabelas 2 e 3 ), assim como, diferen tes composições mineralógicas desta fração (Tabela 1).

Em todos os solos, os valores de densidade de carga foram sempre maiores nos horizontes Ap. Isto deve estar relacionado a maior quantidade de matéria orgânica exis tente nestes horizontes, uma vez que seus teores de argila são sempre menores que aqueles dos horizontes B2.

\subsection{Equilíbrio de troca}

As quantidades de potássio e cálcio adsorvidos, a razão entre estes cảtions (RPT) e a densidade de carga super ficial em função da razão de adsorção de potássio (RAP) e pH da solução de equilíbrio, para os solos estudados, assim como as constantes de Gapon, são apresentados nas Tabelas 5, 6, 7 , $8,9,10,11,12,13$ e 14 .

Considerando no equilỉbrio catiônico, potássio trocando câlcio, com o aumento do $\mathrm{pH}$ a tendência observada foi da densidade de carga aumentar, causando, consequentemente, uma diminuição na constante de Gapon e RPT (Tabelas de 5 a 14). Es se comportamento foi observado por outros autores quando estudaram o equilibrio Na-Ca (PRATT et alii, 1962; GALINDO e BINGHAM, 1977 e KINJO, 1980), uma vez que, a medida em que a densi dade de carga superficial dos solos aumenta, os câtions diva - 


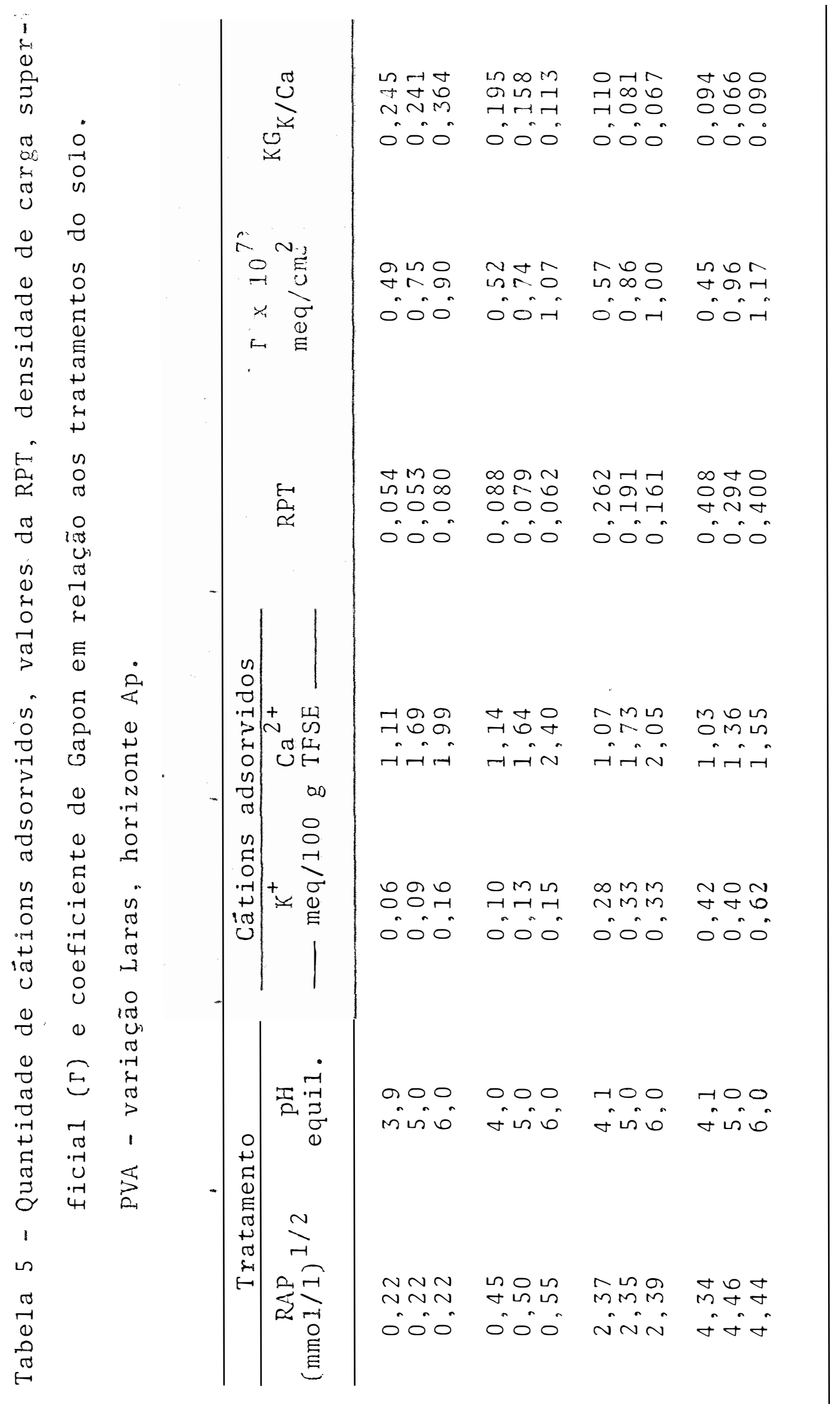




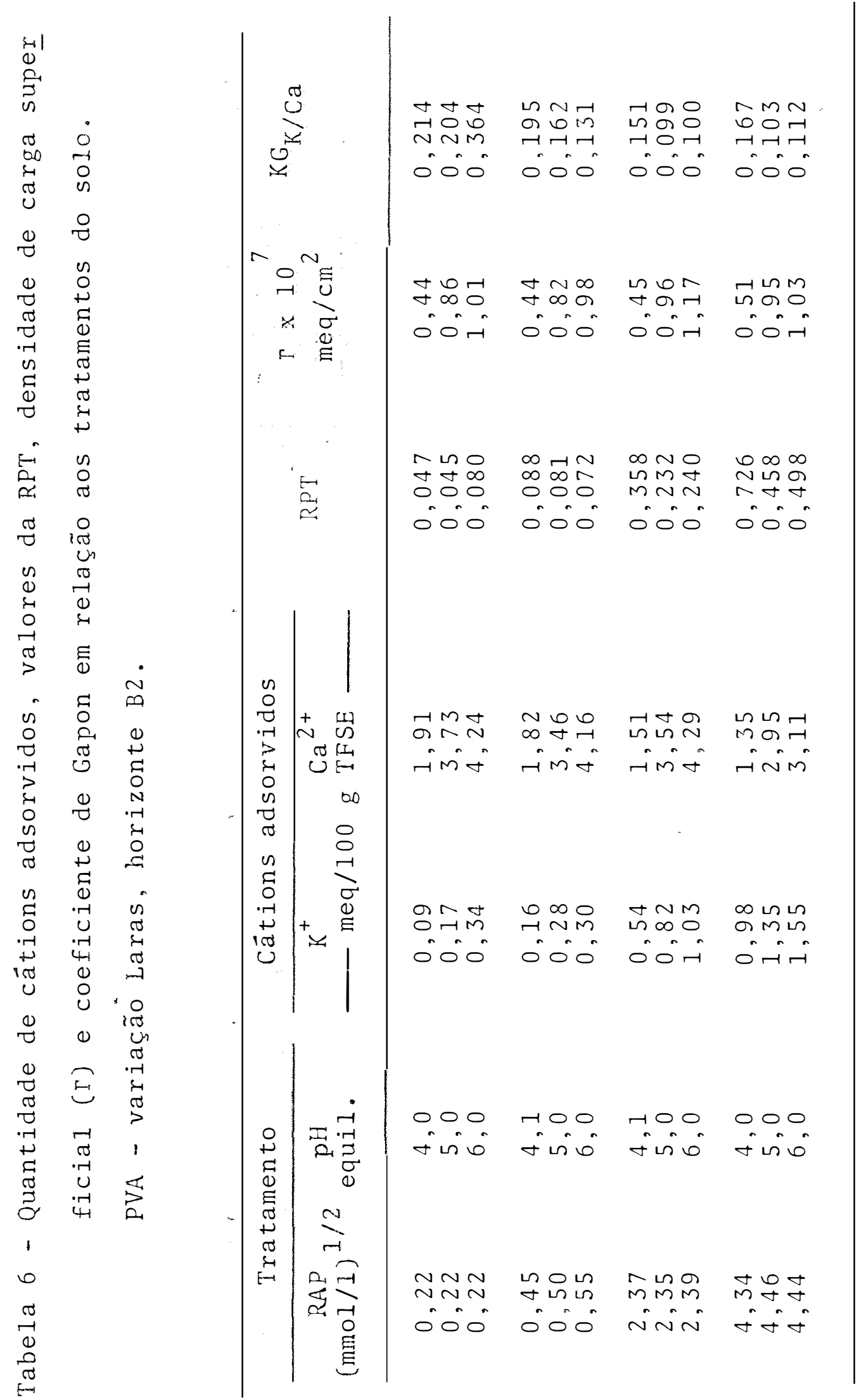




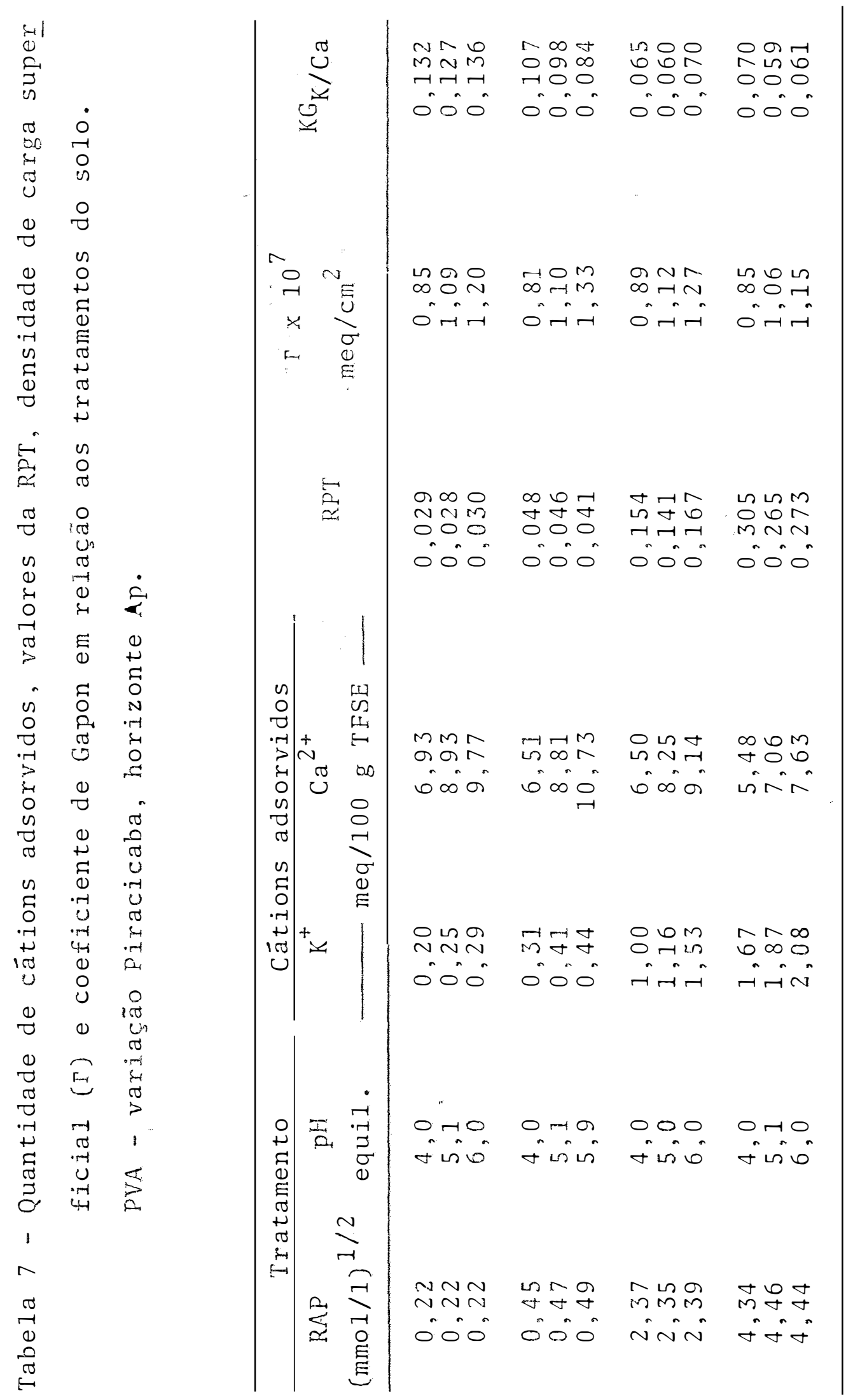



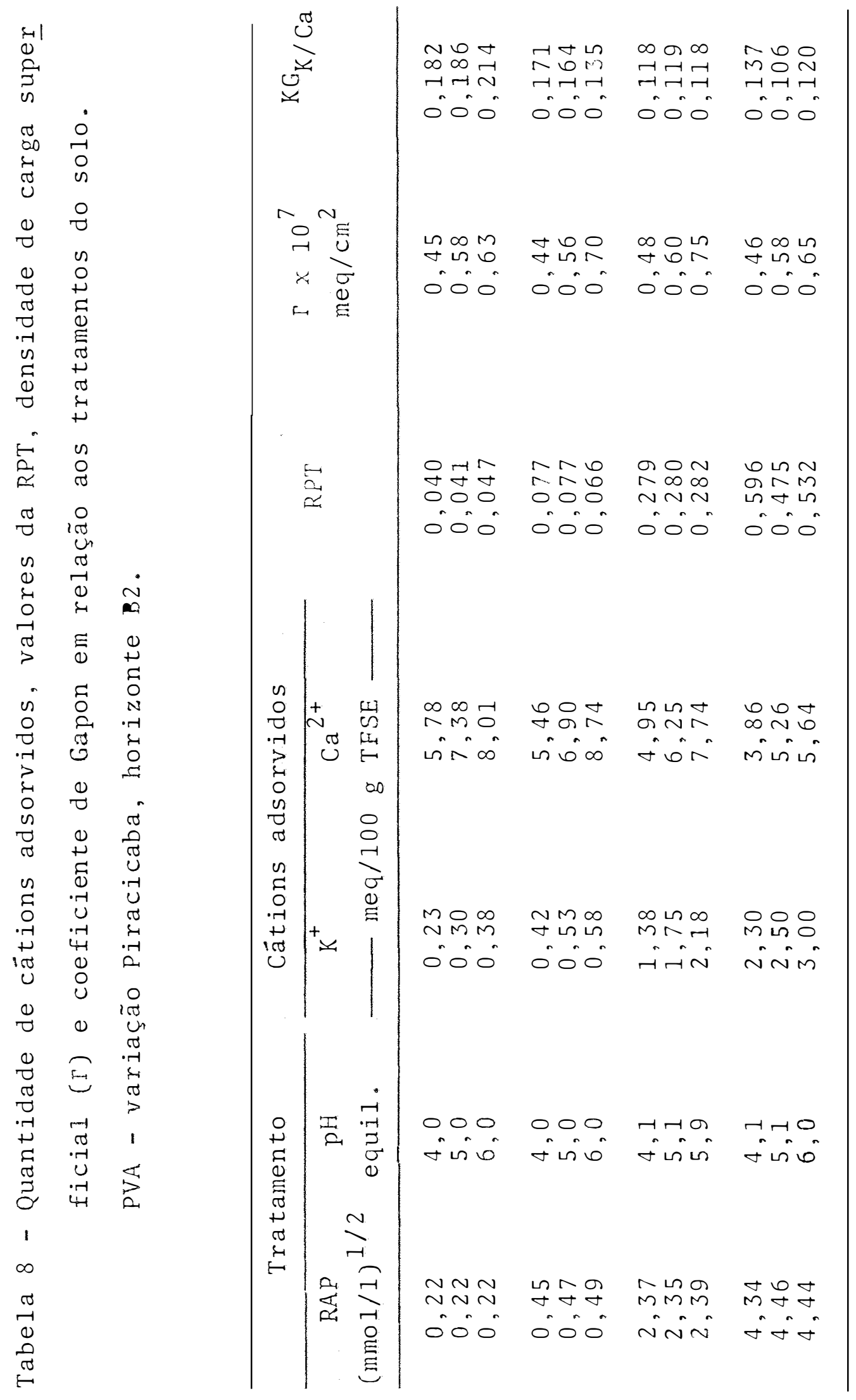


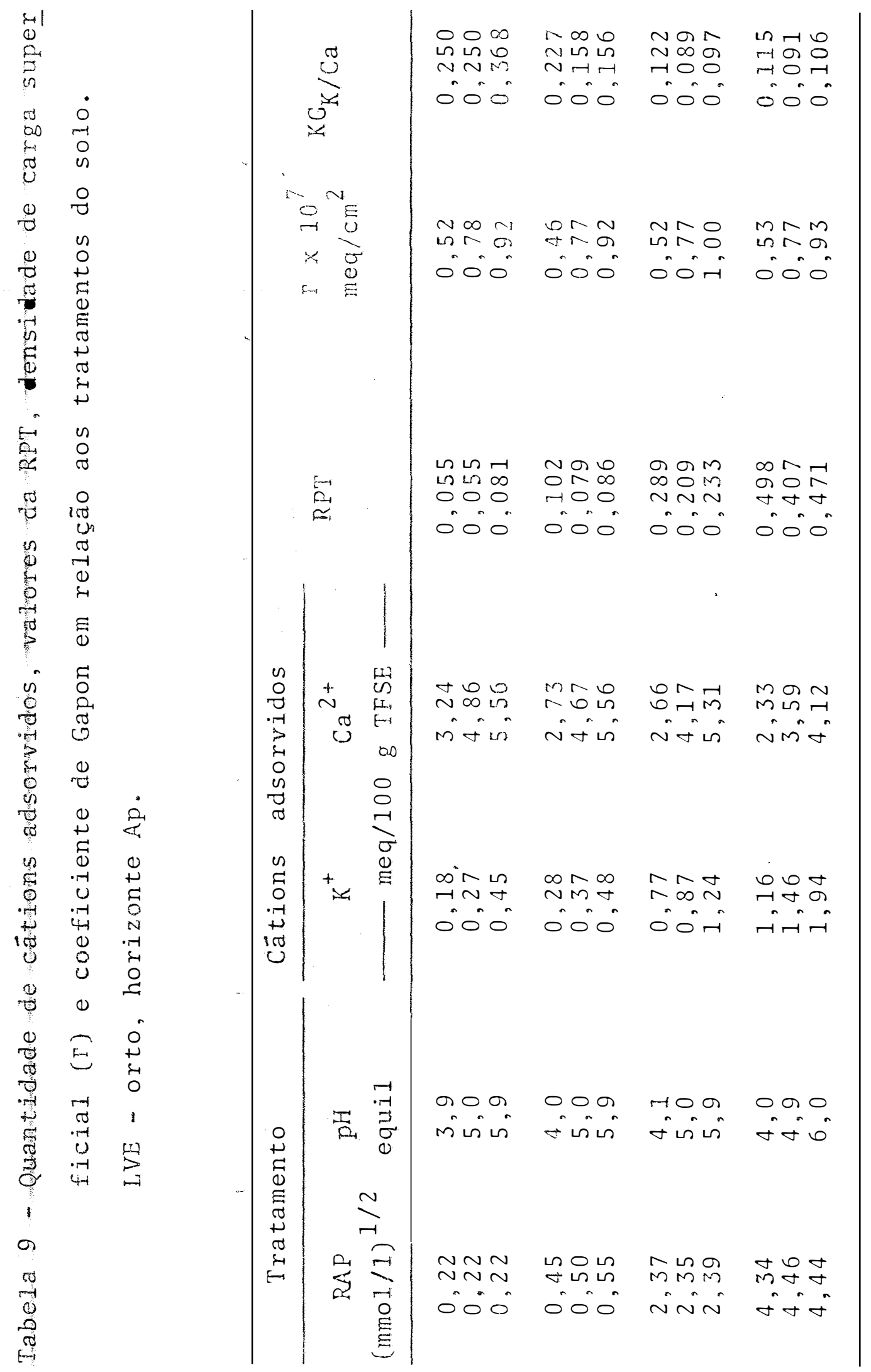



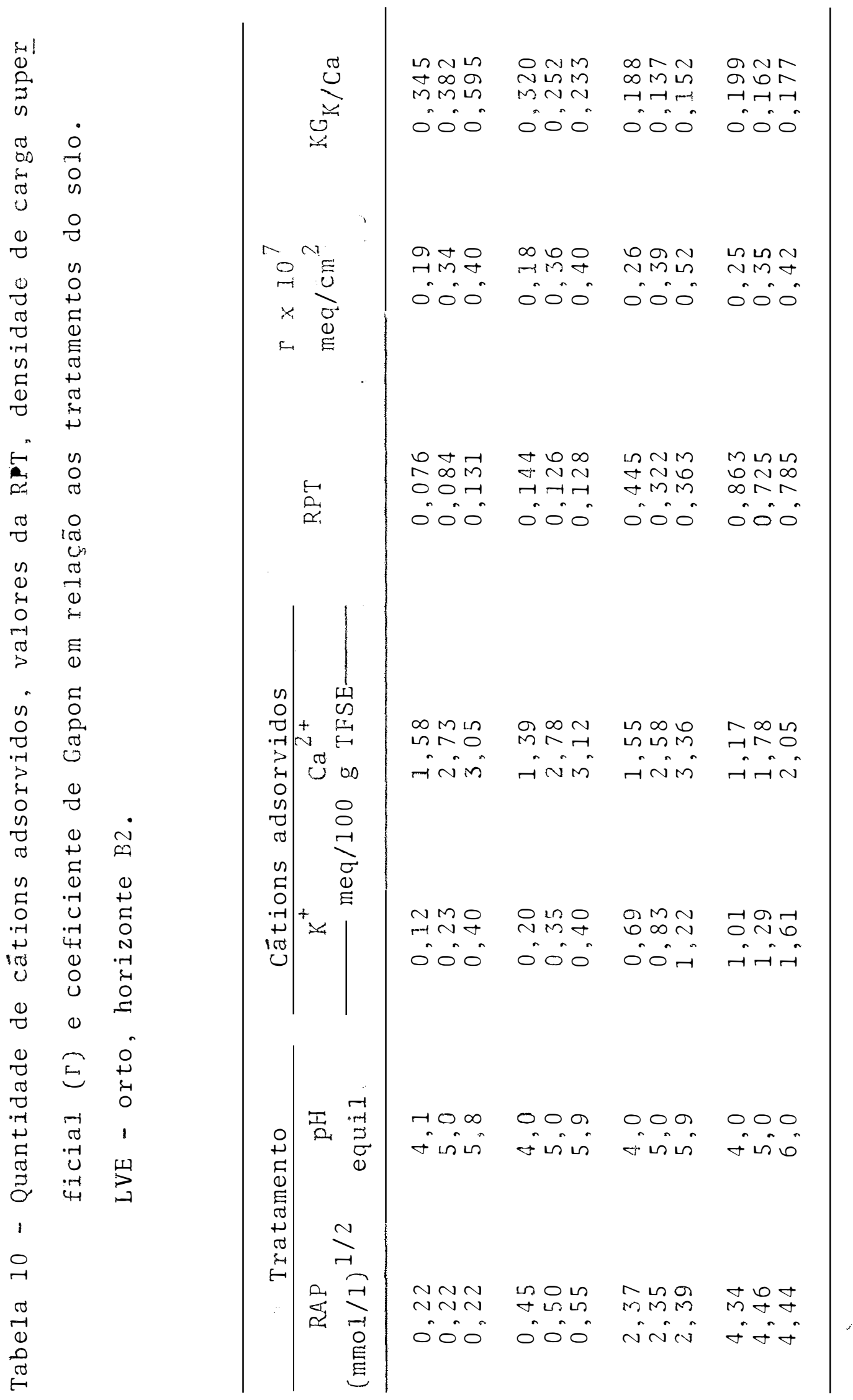


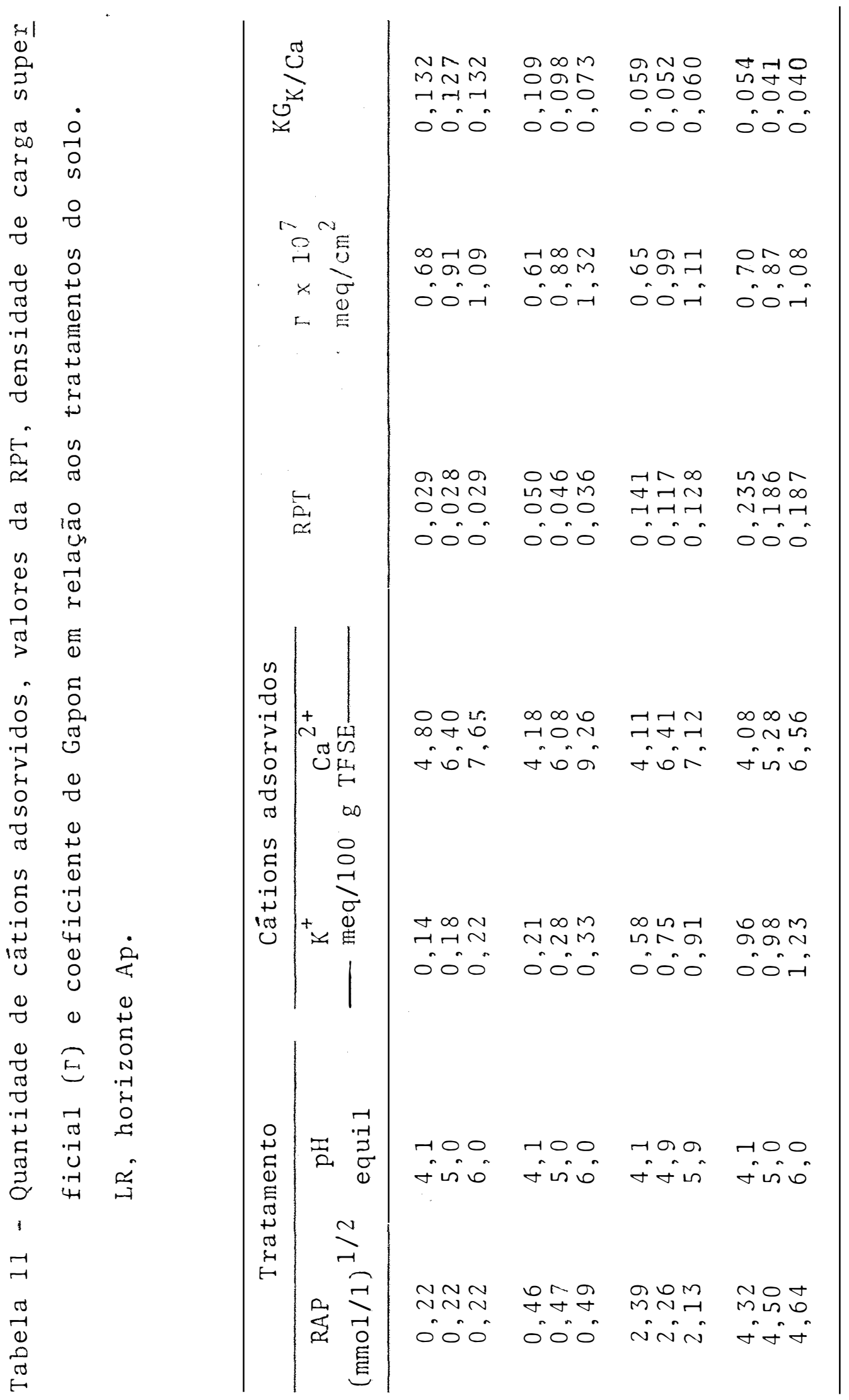




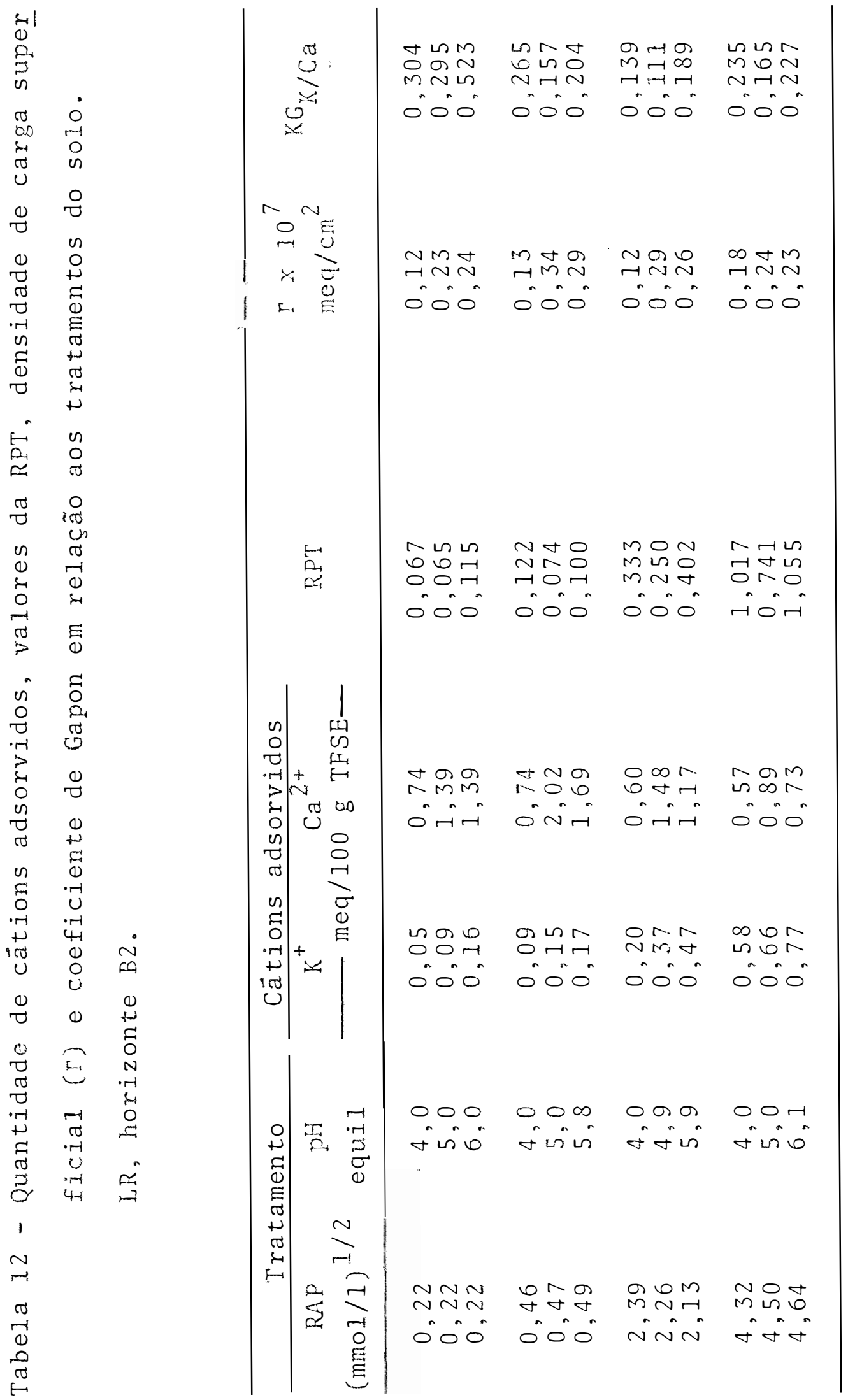


4
0
0
0
0
0
0
$i=1$
0
0
0
0
0
0
0
0
0
0
0
0
0

a

E.

艺

o

¿

$\stackrel{0}{>}$

is

0
0
0
0
0

豕

in

o

E

点

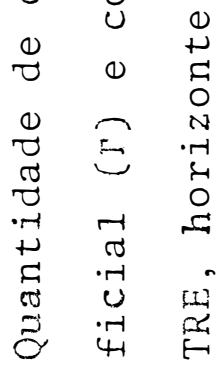

I

$m$

0
0
0
0
0
0

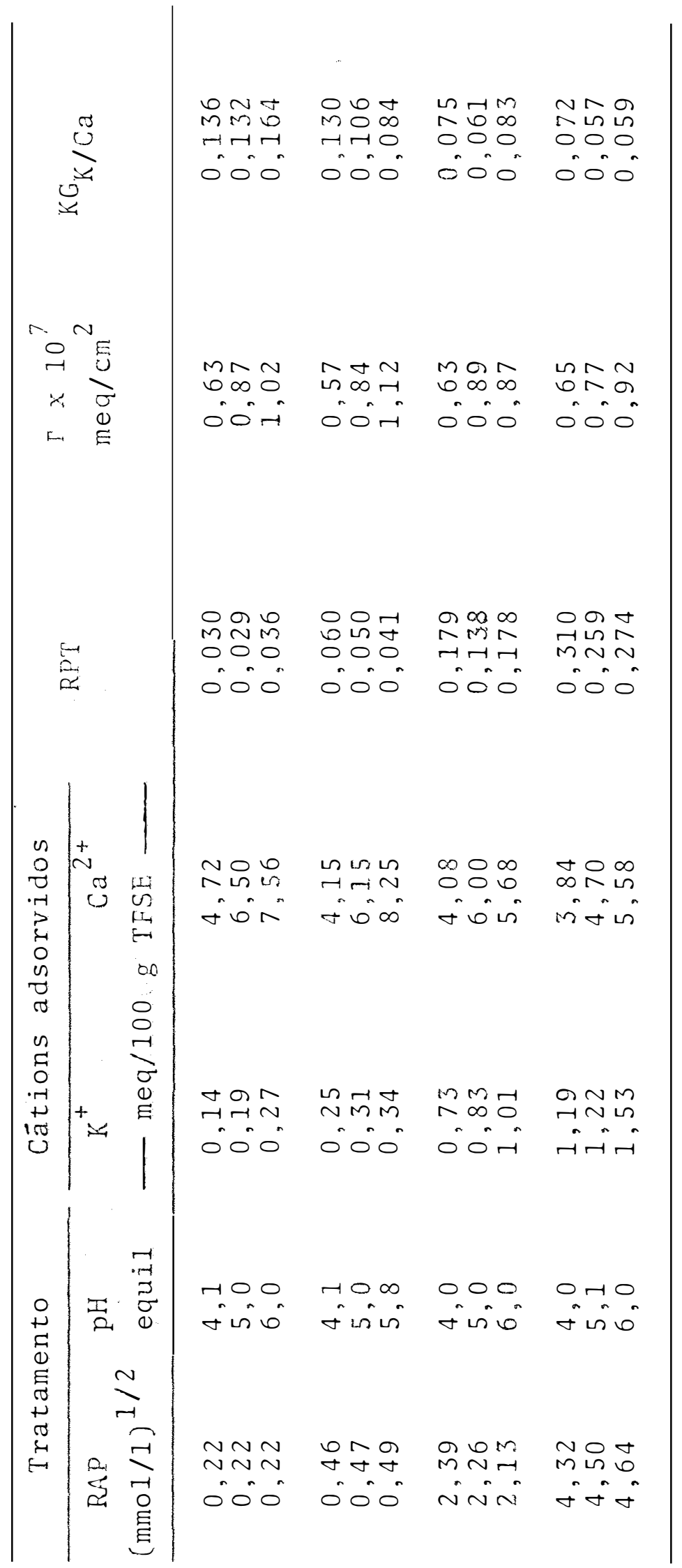



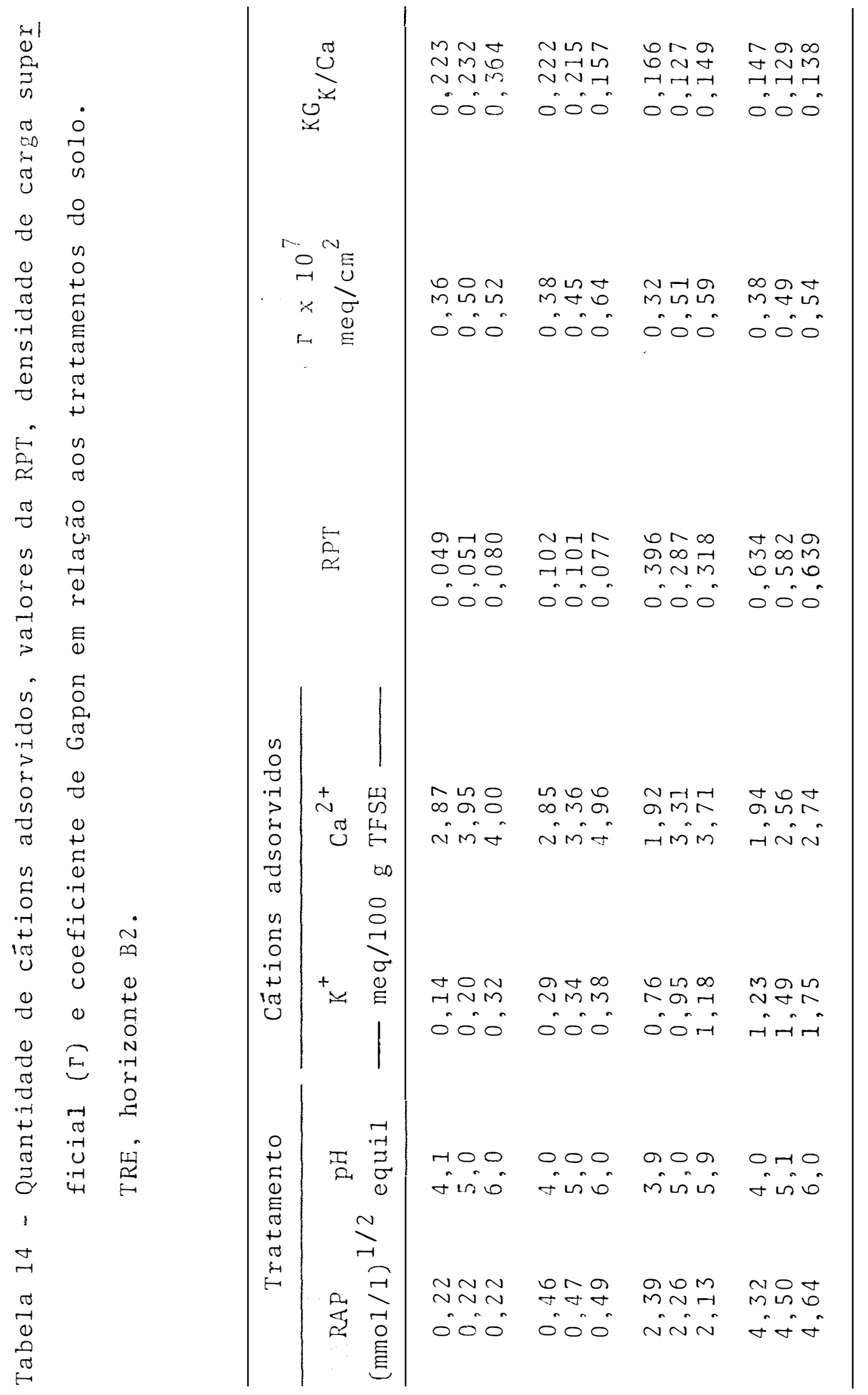
lentes da solução do solo são adsorvidos preferencialmente em relação aos monovalentes (BOLT, 1955).

Comparando-se os valores da constante de Gapon encontrados para os horizontes Ap e B2 de todos os solos, com exceção daqueles correspondentes a RAP igual a 0,22 do PVA variação Laras, os dos horizontes B2 foram sempre superiores aos dos horizontes Ap, o que indica a ocorrência de maior adsorção de potâssio em relação ao câlcio naqueles horizontes. Isto pode ser explicado baseado no fato de que o horizonte B2, em todos os solos, possui densidade de carga superficial menor que o horizonte Ap (Figura 2).

Os valores da RPT, correspondentes aos pH 4 e 6, em sua maioria, variaram inversamente com a densidade de carga superficial, indicando que o acúmulo de cálcio em rela ção ao potâssio foi favorecido pelo aumento da densidade de carga superficial.

Resultados semelhantes foram observados. por SCHALSCHA et alii (1975). Em alguns solos os valores da RPT não apresentaram o mesmo comportamento. No horizonte Ap do PVA-variação Piracicaba e do LR, para uma RAP igual a 0,22 não houve variação. Jä nos horizontes Ap e B2 do PVA-variação Piracicaba e horizonte $B 2$ do LR para uma RAP igual a 2,0 e horizonte B2 do LR para uma RAP igual a 4,0, a variação da RTP foi 
diretamente proporcional a densidade de carga superficial. Tais exceções devem ter ocorrido por erro experimental, uma vez que nos solos estudados, por predominarem colóides com superfície de carga variảvel, as cargas negativas aumentam com a elevação do $\mathrm{pH}$ e, consequentemente, a densidade de carga superficial dos solos.

Os valores da RP' de acordo com a equação de Gapon, se correlacionam linear e positivamente com os da RAP, para todos os solos estudados (Tabelas, 15, 16 e 17). Pode-se dizer com isto, que para uma RAP de até $4,4(\operatorname{mol} / 1)^{1 / 2}$, a equação de Gapon preve a adsoxção de potássio em relação a sua concentração e a do cảlcio na solução do solo.

A influência da densidade de carga superficial dos solos, na variação da RPT em função da RAP, pode ser obser vada na Figura 3. Esta variação, como comentado anteriormente, foi diretamente proporcional, tendo ocorrido, porém, com inten sidades diferentes para cada faixa de densidade de carga super ficial considerada. Assim, para uma mesma RAP, a medida em que a densidade de carga superficial dos solos aumentou, a RPT diminuiu, indicando o aumento na adsorção preferencial de cảlcio nos solos.

As Figuras $4,5,6$ e 7 mostram como se relacionam os valores da RPT com os de densidade de carga superficial 
Tabela 15 - Regressão linear relacionando RPT (y) com RAP (x) e respectivos coeficientes de correlação ( $r$ ) para os 3 niveis de pH da solução de equilỉbrio nos so los PVA-variação Laras e PVA-variação Piracicaba.

\begin{tabular}{|c|c|c|c|c|c|}
\hline Horizonte & $\mathrm{pH}$ & & Regressão 1 inear & & $\mathrm{r}$ \\
\hline & & PVA & - variacão Laras & & \\
\hline \multirow[t]{4}{*}{ Ap } & 4,0 & y & $=0,046+0,085 x$ & & $0,998 *$ * \\
\hline & 5,0 & y & $=0,048+0,056 x$ & & $0,997 * *$ \\
\hline & 6,0 & y & $=0,029+0,077 x$ & & $0,966 * *$ \\
\hline & Total & y & $=0,041+0,073 x$ & & $0,958 * *$ \\
\hline \multirow[t]{5}{*}{ B2 } & 4,0 & y & $=0,005+0,1624$ & & $0,997 * *$ \\
\hline & 5,0 & y & $=0,024+0,0955$ & $\mathrm{x}$ & $0,998 * *$ \\
\hline & 6,0 & y & $=0,030+0,1015$ & $x$ & $0,990 * *$ \\
\hline & Total & y & $=0,020+0,1190$ & $\mathrm{x}$ & $0,942 * *$ \\
\hline & & PVA & - variação Piraci & $c a b a$ & \\
\hline \multirow[t]{4}{*}{ Ap } & 4,0 & y & $=0,013+0,0656$ & $x$ & $0,997 * *$ \\
\hline & 5,0 & y & $=0,016+0,0552$ & $x$ & $0,999 * *$ \\
\hline & 6,0 & y & $=0,017+0,0587$ & $x$ & $0,998 * *$ \\
\hline & Total & y & $=0,016+0,0597$ & $x$ & $0,993 *$ * \\
\hline \multirow[t]{4}{*}{ B2 } & 4,0 & y & $=0,005+0,1318$ & $x$ & $0,995 * *$ \\
\hline & 5,0 & y & $=0,027+0,1019$ & $x$ & $0,999 * *$ \\
\hline & 6,0 & y & $=0,013+0,1157$ & $x$ & $0,999 * *$ \\
\hline & Total & y & $=0,015+0,1162$ & $x$ & $0,989 * *$ \\
\hline
\end{tabular}


Tabela 16 - Regressão linear relacionando RPT (y) com RAP (x) e respectivos coeficientes de correlação ( $r$ ) para os 3 niveis de pH da solução de equilíbrio nos so Ios LVE-orto e Latossol Roxo.

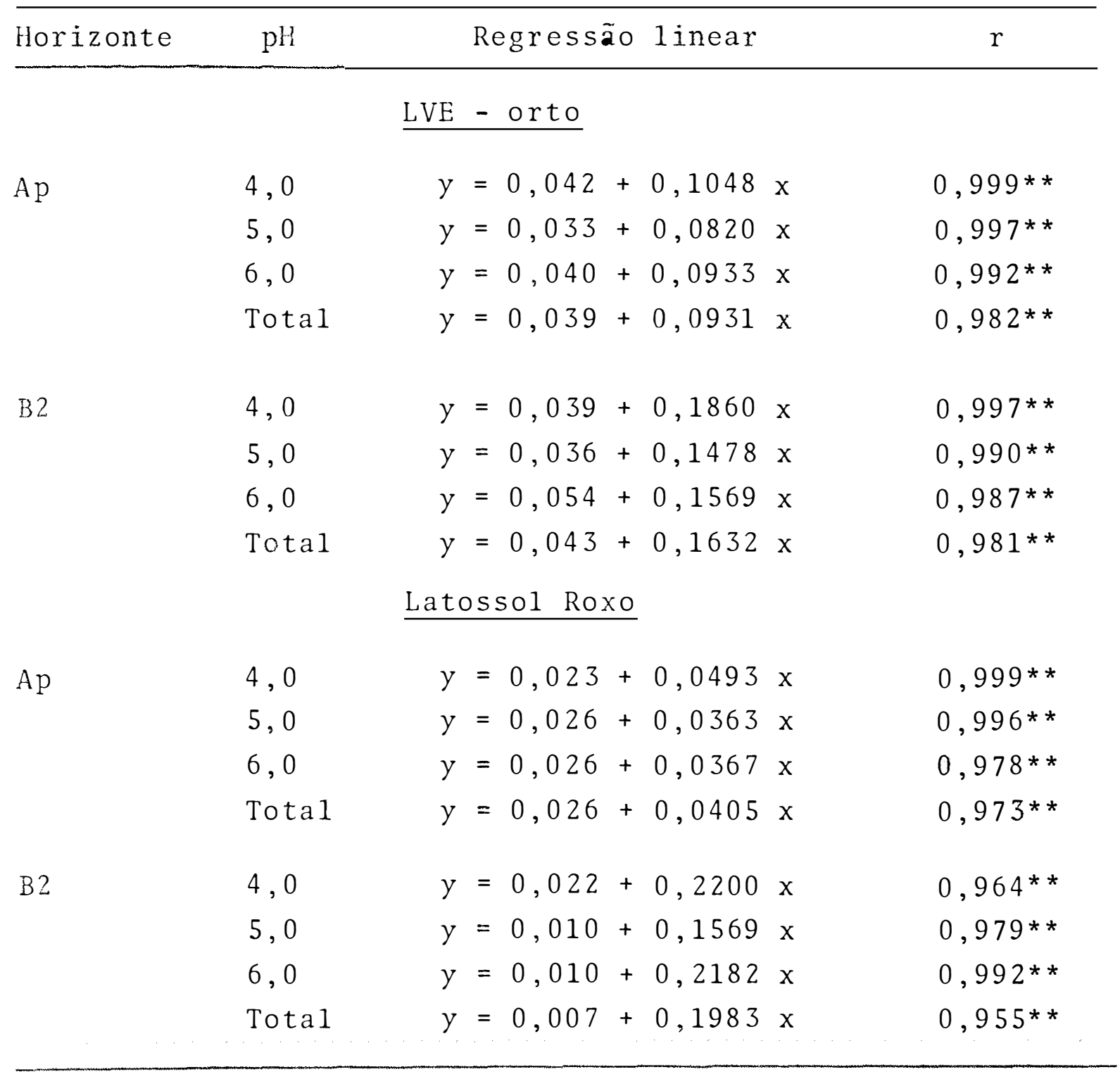


Tabela 17 - Regressão linear relacionando $\operatorname{RPT}(y) \operatorname{com} \operatorname{RAP}(x)$ e respectivos coeficientes de correlação (r) para os 3 níveis de pH da solução de equilíbrio no so 1o Terra Roxa Estruturada.

\begin{tabular}{|c|c|c|c|c|c|c|c|}
\hline Horizonte & $\mathrm{pH}$ & & & Regres & $s \tilde{a}$ & o linear & $\mathrm{r}$ \\
\hline \multirow[t]{4}{*}{$A p$} & 4,0 & y & $=$ & 0,022 & + & $0,0666 x$ & 0,999 * * \\
\hline & 5,0 & y & $=$ & 0,021 & + & $0,0528 x$ & $0,999 * *$ \\
\hline & 6,0 & $y$ & $=$ & 0,028 & + & $0,0557 \times$ & $0,983 * *$ \\
\hline & Tota 1 & y & $=$ & 0,024 & + & $0,0581 x$ & $0,983 * *$ \\
\hline \multirow[t]{4}{*}{$B 2$} & 4,0 & $y$ & $=$ & 0,033 & + & $0,1421 x$ & 0,998 * * \\
\hline & 5,0 & $y$ & $=$ & 0,029 & + & $0,1212 x$ & $0,998 * *$ \\
\hline & 6,0 & y & - & 0,034 & + & $0,1305 x$ & $0,998 *$ * \\
\hline & Tota 1 & $y$ & $=$ & 0,033 & + & $0,1310 x$ & $0,993 * *$ \\
\hline
\end{tabular}




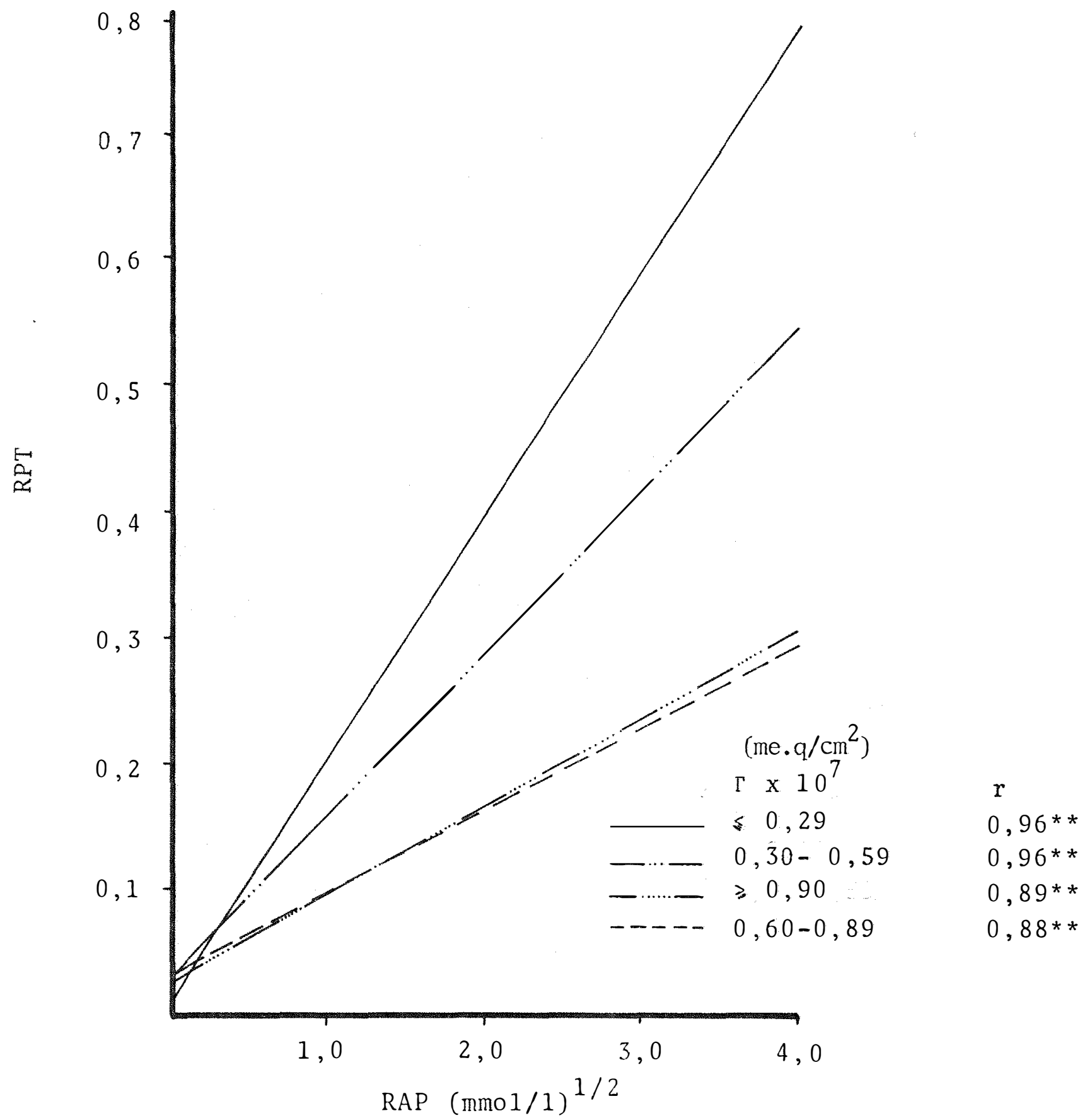

Figura 3 - Variação da razão de potāssio trocâvel (RPT) em função da razão de adsorção de potássio (RAP) para os diferentes intervalos de densidade de carga superficial dos solos $(\Gamma)$. 
para cada nível da RAP. Para a curva teórica, que foi obtida através da equação da dupla camada, simplificada por BOLT (1955), a RPT foi determinada a partir da fração da carga superficial neutralizada pelo potássio $\left(\Gamma_{1} / \Gamma\right)$, da seguinte maneira:

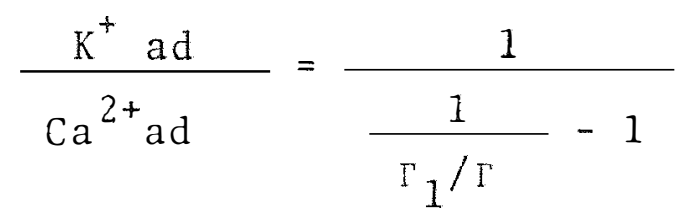

Observa-se nas figuras acima citadas, que as curvas teöricas localizaram-se num plano inferior aos dados ex perimentais, tendendo a se aprcximar deles, à medida em que os valores de RAP aumentaram.

Vârios autores, estudando o equilíbrio $\mathrm{Na}-\mathrm{Ca}$, ajustaram as curvas teóricas aos dados experimentais, multipli cando a densidade de carga superficial da equação da dupla camada, por uma determinado fator para corrigir a fração $\Gamma_{1} / \Gamma$, e a partir desta, a relação $\mathrm{Na}_{\mathrm{ad}} / \mathrm{Ca}$ ad (BOLT, 1955; PRATT et alii, 1962 e KINJO, 1980). Neste trabalho não foi possivel corrigir as curvas teóricas da mesma maneira. Acredita-se que isto tenha ocorrido, provavelmente, porque, para valores baixos da RAP a equação da dupla camada não se ajusta satisfatoriamente aos dados experimentais, ao contrário do que ocorreu para a RAS 100 (PRATT et alii, 1962) e RAS 7;10;13,4;18,9:e 41,6 (KINJO, 1980$)$. 


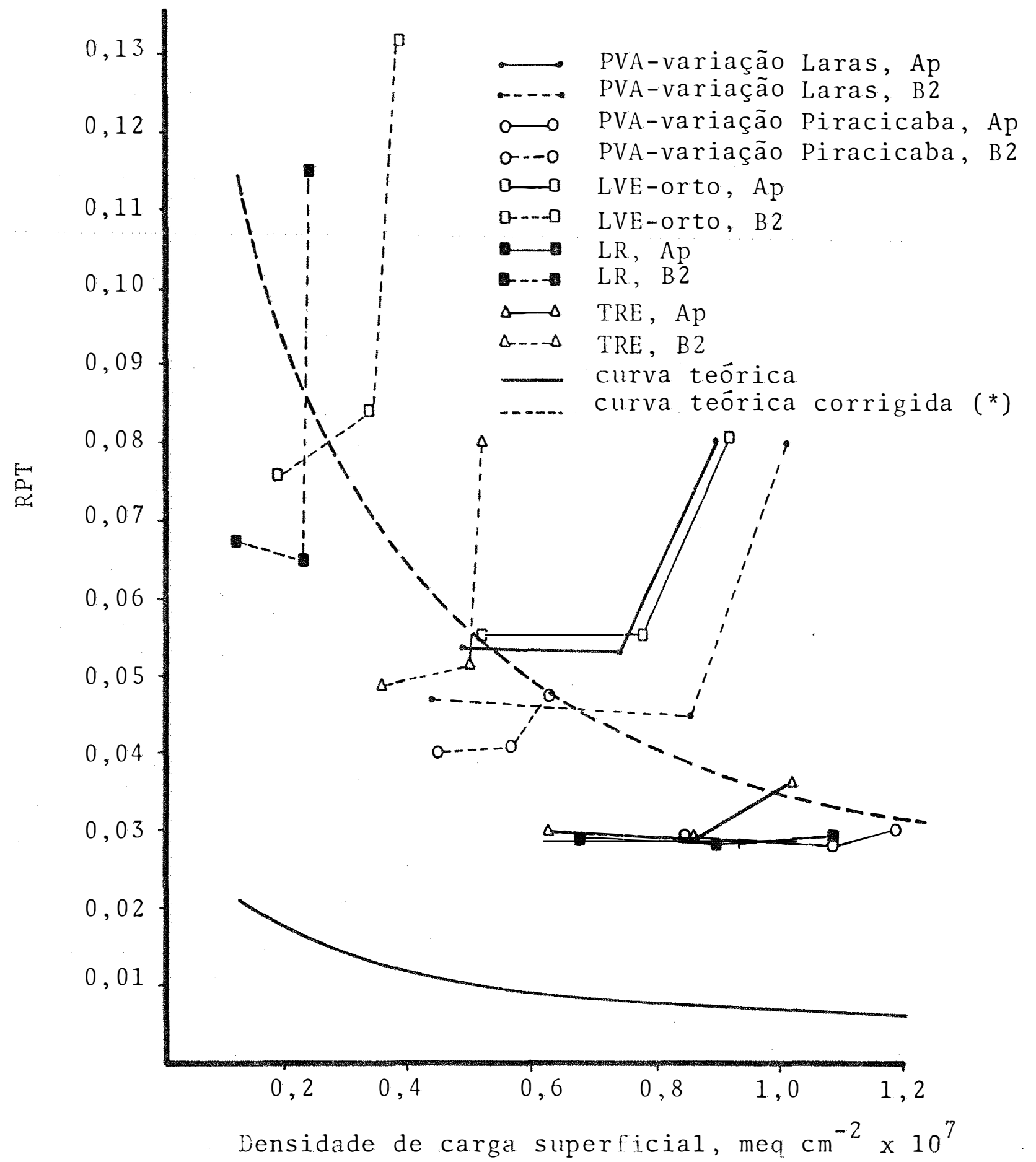

Figura 4 - Relação entre a razão de potássio trocável (RPT) e a densidade de carga superficial para RAP=0,22 .

${ }^{*}$ ) curva teórica obtida com a fração $\Gamma_{1} / r$ multiplicada por um fator de 5,0. 


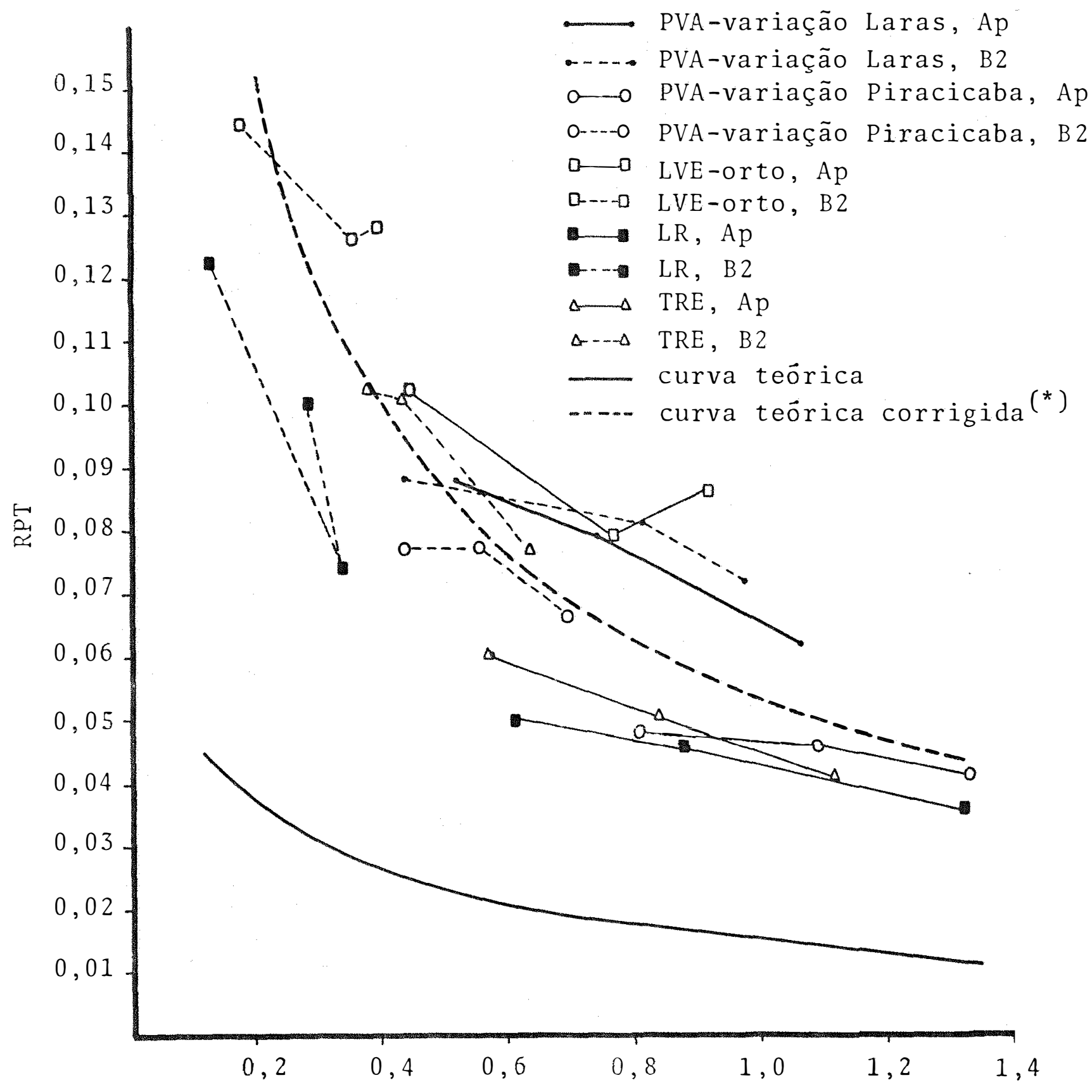

Densidade de carga superficial, meq $\mathrm{cm}^{-2} \times 10^{7}$

Figura 5 - Relação entre a razão de potāssio trocável (RPT) e a densidade de carga superficial para $\operatorname{RAP}=0,4$.

(*) curva teörica obtida com a fração $\Gamma_{1} / \Gamma$ multiplicada por um fator de 3,5 . 


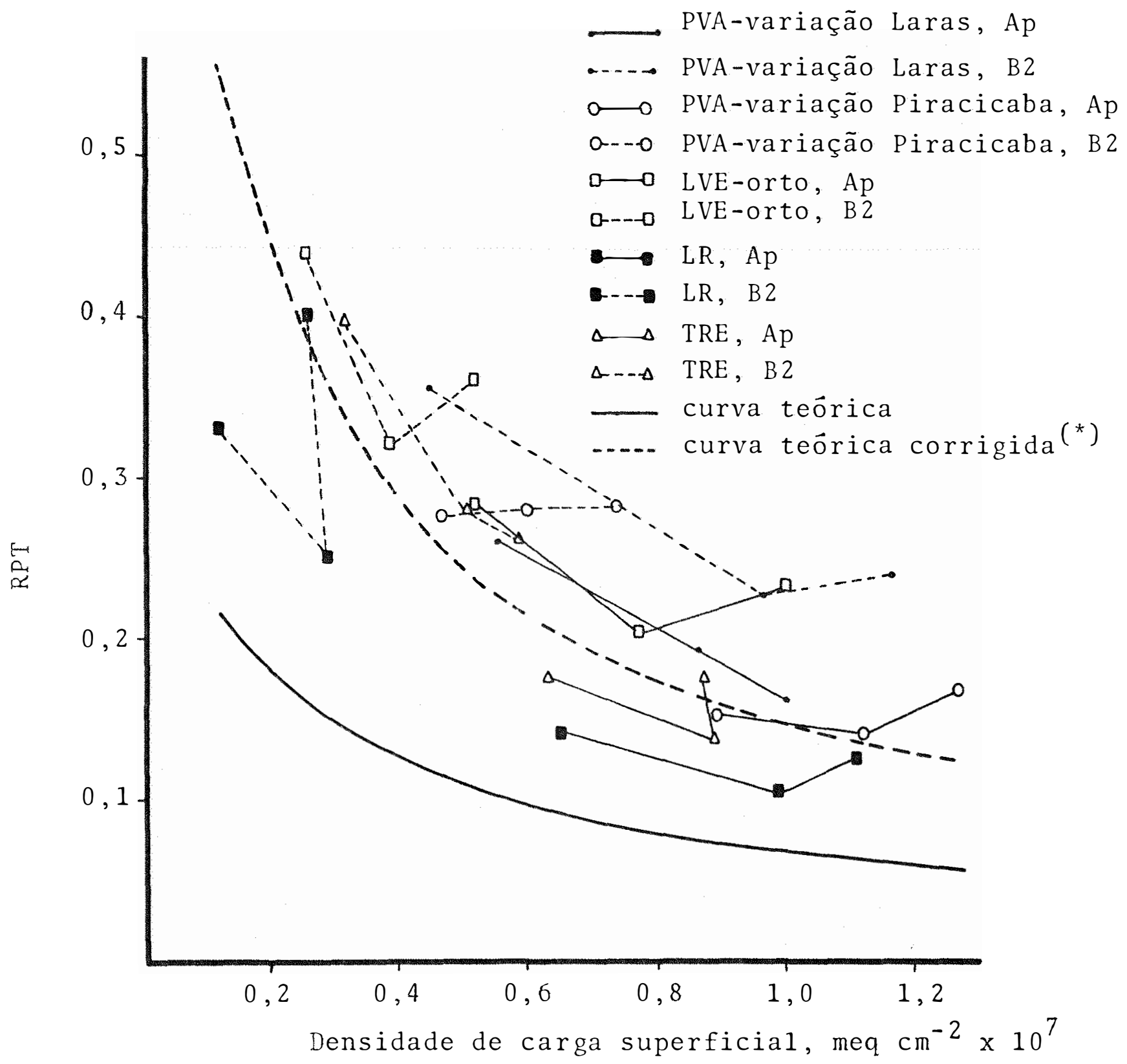

Figura 6 - Relação entre a razão de potảssio trocảvel (RPT) e a densidade de carga superficial para RAP $=2,0$

(*) curva teórica obtida com a fração $\Gamma_{1} / \Gamma$ multiplicada por um fator de 2,0. 


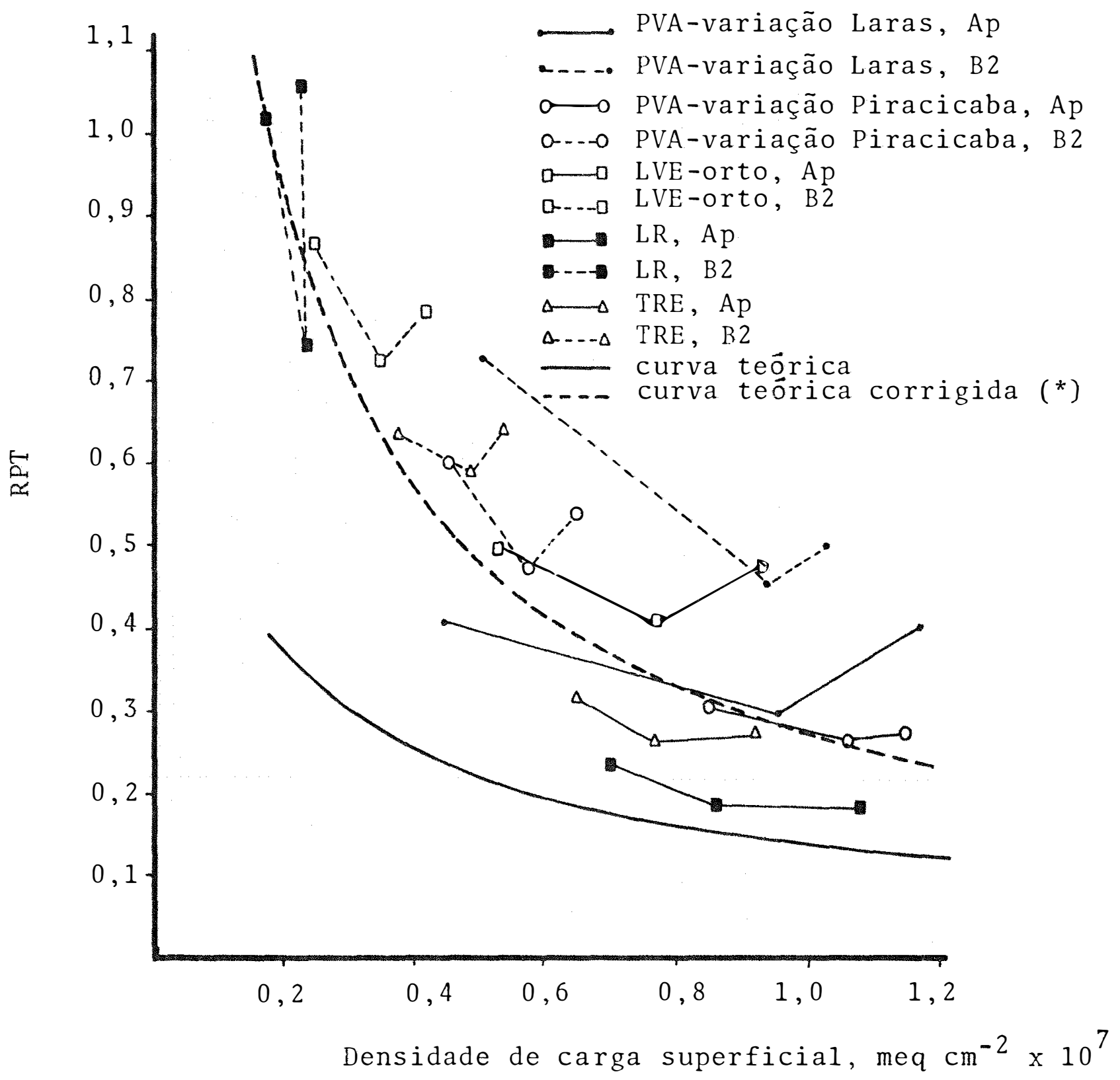

Figura 7 - Relação entre a razão de potâssio trocâvel (RPT) e a densidade de carga superficial para RAP $=4,0$

(*) curva teórica obtida com a fração $\Gamma_{1} / \Gamma$ multiplica da por um fator de 1,8 . 


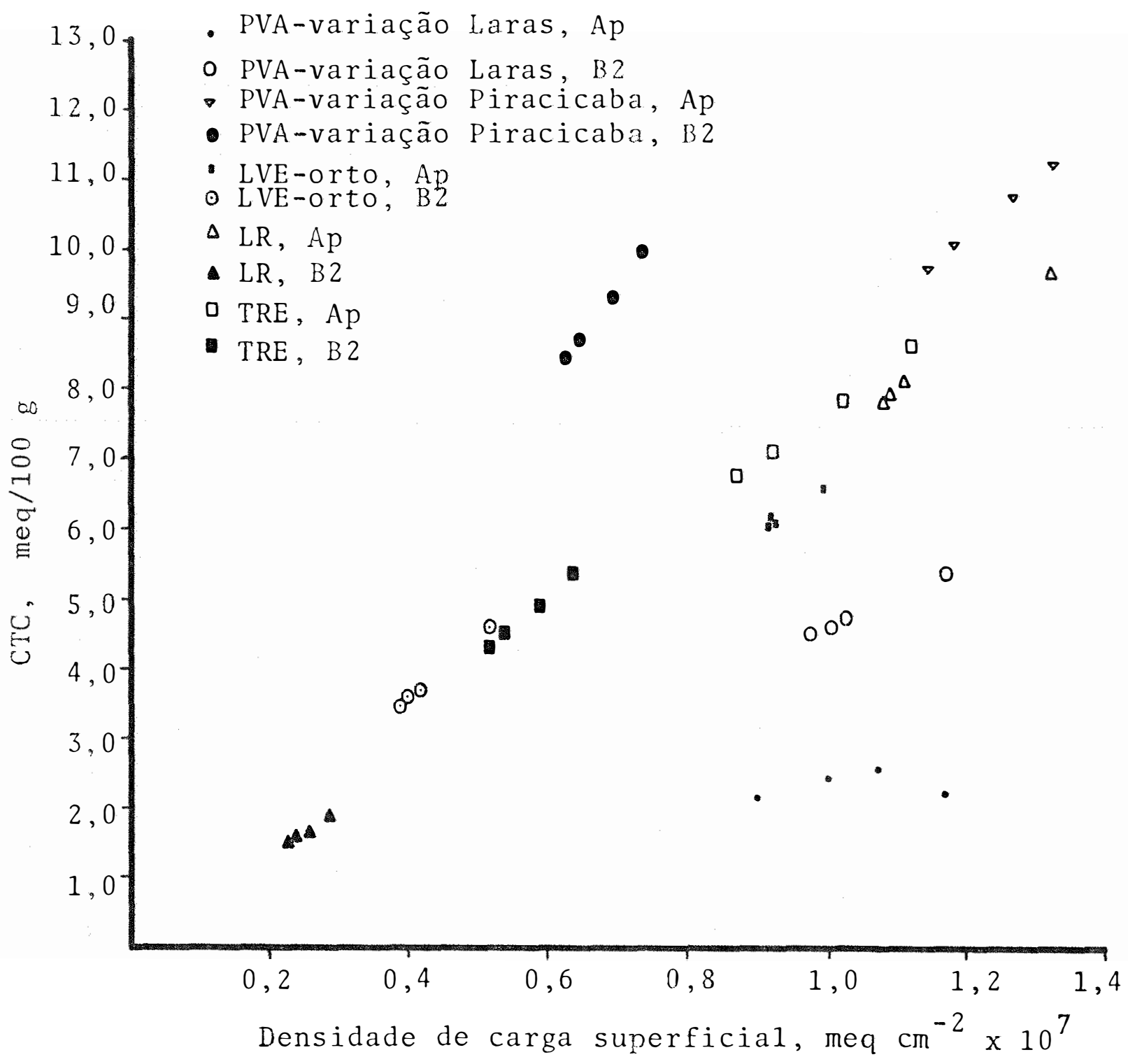

Figura 8 - Variação da capacidade de troca catiônica (CTC), à pH 6,0, em função da densidade de carga superficial dos solos estudados aos quatro níveis da RAP. 
Na tentativa de se ajustar as curvas teóricas aos dados experimentais, multiplicou-se, não a densidade de carga superficial da equação da dupla camada, mas sim as fra ções $\Gamma_{1} / \Gamma$ pelos seguintes fatores: 5 para RAP 0,$22 ; 3,5$ para RAP 0,$40 ; 2$ para RAP 2,0 e 1,8 para RAP 4,0. Para comprovar se os ajustes foram adequados, correlacionou-se os valores experimentais e teöricos corrigidos da RPT. Os coeficientes de correlação ( $r$ ) encontrados foram altamente significativos (Figuras 4, 5, 6 e 7 ), e os de determinação $\left(\mathrm{r}^{2}\right)$, mostraram que para RAP 0,$22 ; 0,40 ; 2,0$ e 4,0 , a curva teórica corrigida explica $23,64,52$ e $74 \%$, respectivamente, da variação dos dados experimentais.

Pela Figura 8, observa-se que a variação da CTC a pH 6,0, è diretamente proporcional a da densidade de carga superficial, apesar dela ocorrer com intensidades dife rentes em cada solo e mesmo em cada horizonte de um mesmo so 1o. Essa diferença é explicada pelo fato dos coeficientes de proporcionalidade entre CTC e densidade de carga superficial, no caso, os valores de superfície específica dos solos, serem diferentes para cada horizonte.

Da mesma maneira que a variação da RPT foi inversamente proporcional à densidade de carga superficial, ela tambẻm foi em relação a CTC, considerando-se o que foi comen- 
tado no parâgrafo anterior. Porém, correlacionando-se os valores de RPT com os de densidade de carga e de CTC, para RAP igual a 4,0, encontraram-se coeficientes de correlação $r=$ $-0,81^{* *}$ e $\mathrm{r}=-0,54 * *$ e de determinação $\mathrm{r}^{2}=0,66$ e $\mathrm{r}^{2}=0,29$, respectivamente. Isto mostra que $66:$ da variabilidade dos va lores de RPT é explicado pela regressão linear entre RPT e $\Gamma$, o que leva supor que a RPT se correlaciona melhor com a densidade de carga superficial.

\subsection{Lixiviação de potảssio, cảlcio e magnësio.}

As curvas de 1 ixiviação de potâssio e câlcio mais magnësio dos solos LVE-orto, horizontes Ap e B2 e PVA-va riação Piracicaba, horizonte $\Lambda_{p}$, apôs estes terem recebido pul so, são apresentadas nas Figuras 9, 10 e 11 . Estas mostram a concentração dos cảtions em cada volume de percolado coleta do, que para o PVA - variação Piracicaba, pH 5,8 e LVE - orto, horizonte Ap, pH 5,2 foi de $17 \mathrm{ml}$ e para as demais amostras de terra de $10 \mathrm{ml}$.

De modo geral, observa-se que do PVA - variação Piracicaba, lixiviou mais câlcio e magnésio do que das demais amostras de terra (Figura 9). Isto porque ele jâa apresentava, antes da lixiviação, teores maiores destes câtions (Tabela 18). No caso do potảssio, ocorreu justamente o inverso, lixiviou me nos porque o solo apresentava menor teor do elemento (Tabela 19) . 
60.

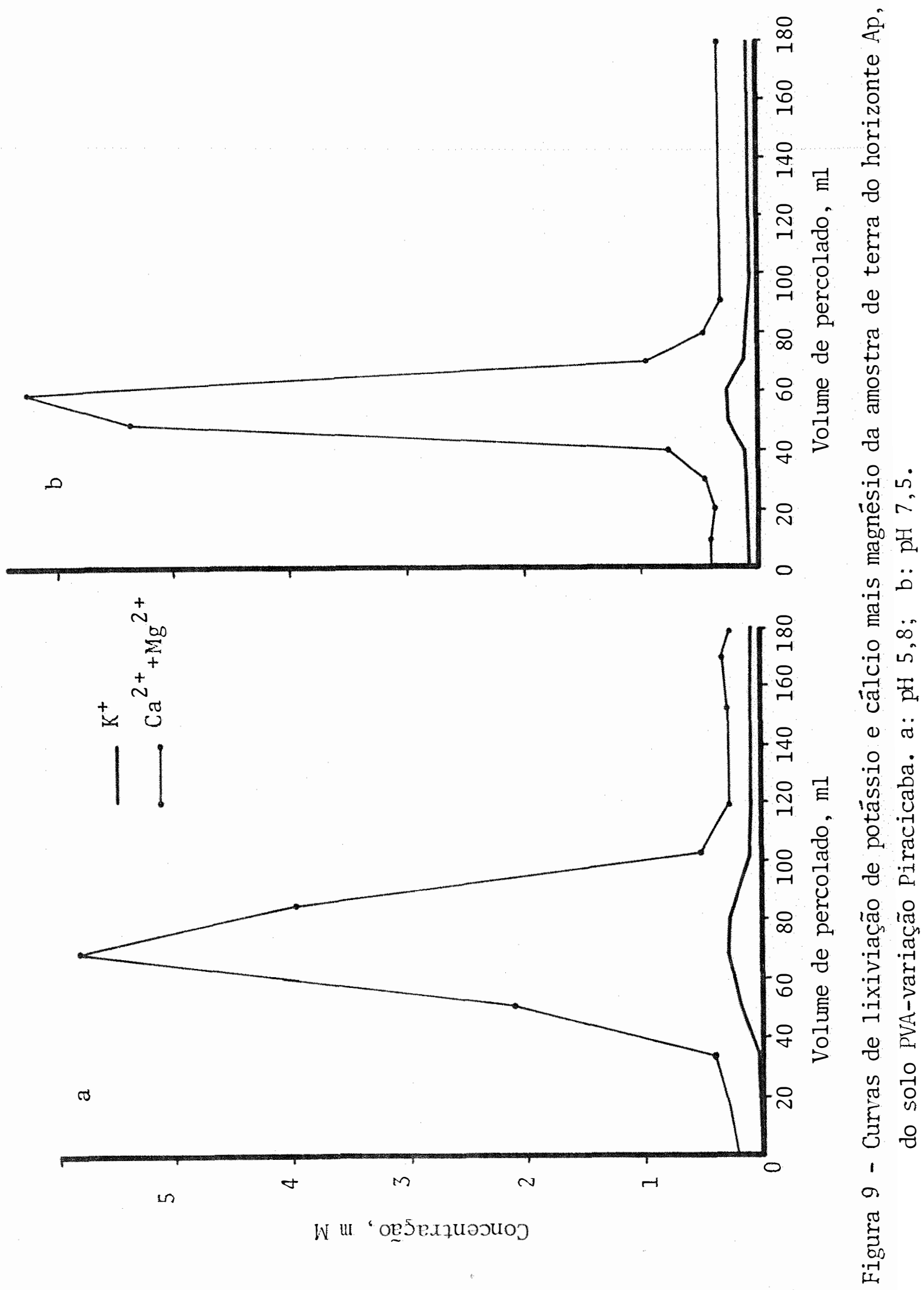




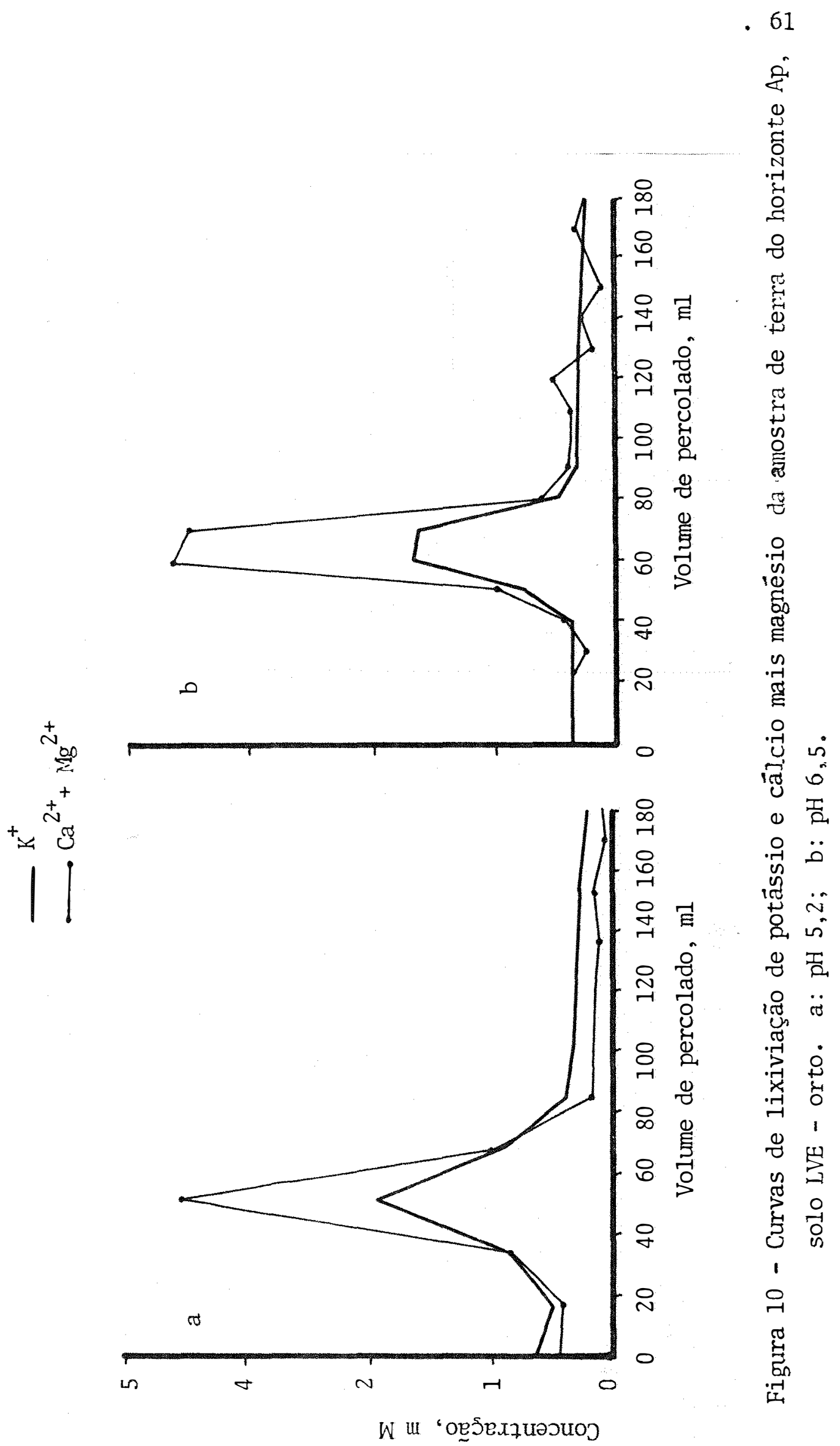




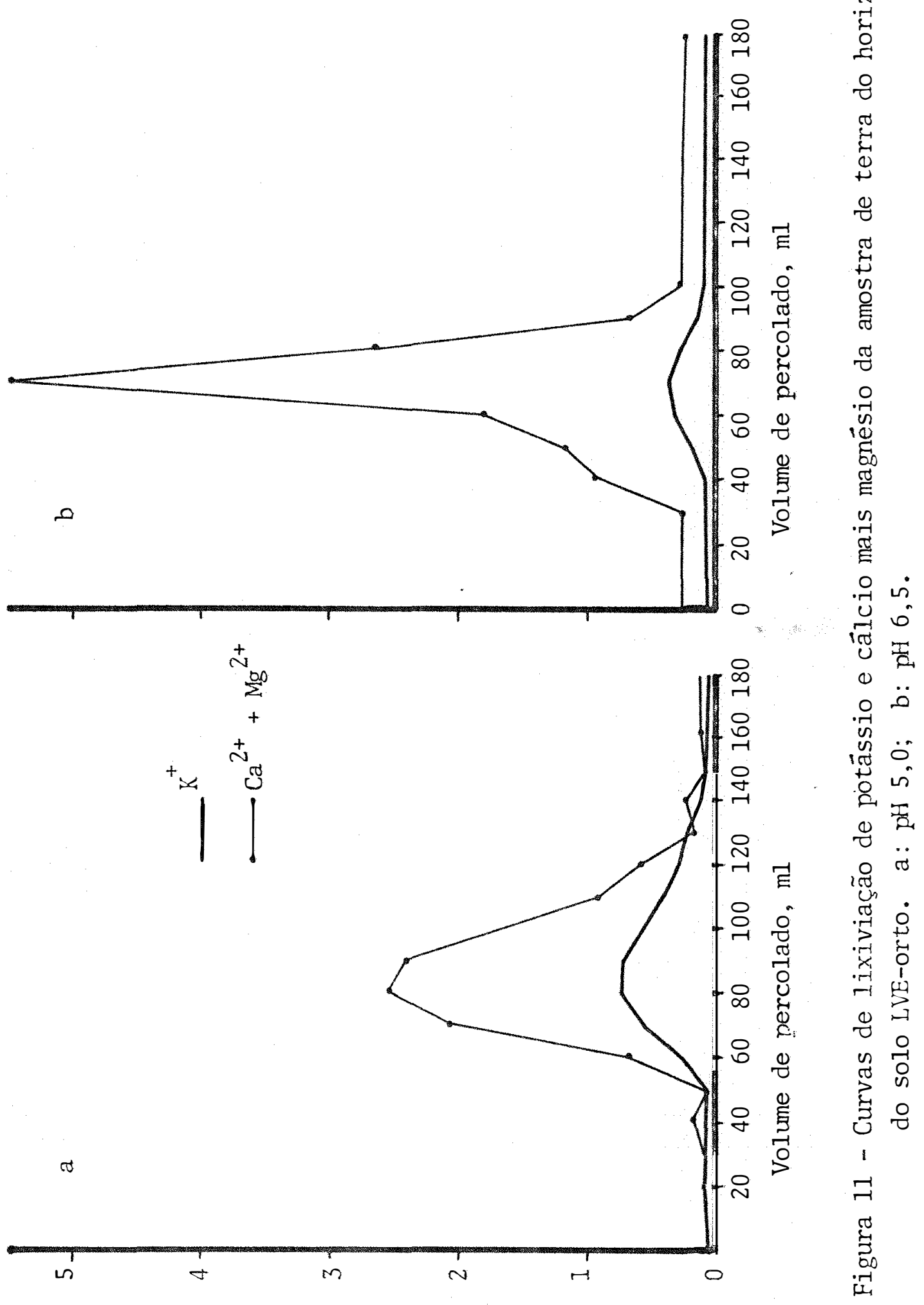

W u "ogfsexzuəวณоว 
Tabela 18 - Quantidade de $\mathrm{Ca}^{2+}+\mathrm{Mg}^{2+}$ trocáveis e quantidade de $\mathrm{Ca}^{2+}$ adicionado à terra, para obter dois níveis de pH, antes da lixiviação, bem como quantidade de $\mathrm{Ca}^{2+}+\mathrm{Mg}^{2+} 1$ ixiviados após o pulso de $\mathrm{K}^{+}$ e quantidade de $\mathrm{Ca}^{2+}+\mathrm{Mg}^{2+}$ retidos na coluna de terra.

\begin{tabular}{|c|c|c|c|c|c|}
\hline \multicolumn{3}{|c|}{ Antes da lixiviação } & \multicolumn{3}{|c|}{ Após lixiviação } \\
\hline \multirow{2}{*}{$\begin{array}{c}\mathrm{pH} \\
\mathrm{da} \\
\text { terra }\end{array}$} & \multirow{2}{*}{$\begin{array}{l}\mathrm{Ca}^{2+}+\mathrm{Mg}^{2+} \\
\text { trocäveis } \\
\text { - meq/100 }\end{array}$} & \multirow{2}{*}{$\begin{array}{l}\mathrm{Ca}^{2+} \\
\text { adicionado } \\
\text { g TFSE }\end{array}$} & \multirow{2}{*}{$\begin{array}{c}\mathrm{Ca}^{2+}+\mathrm{Mg}^{2+} \\
\text { lixiviados } \\
-\mathrm{meq} / 240 \mathrm{ml}-\end{array}$} & \multicolumn{2}{|c|}{$\begin{array}{l}\mathrm{Ca}^{2+}+\mathrm{Mg}^{2+*} \\
\text { retidos }\end{array}$} \\
\hline & & & & meq/100 g & $\div$ \\
\hline & & $\underline{\text { LVE-orto }}$ & horizonte Ap & & \\
\hline 5,2 & 4,14 & - & 0,24 & 3,67 & 88,65 \\
\hline \multirow[t]{2}{*}{6,5} & 4,14 & 4,22 & 0,28 & 7,48 & 89,47 \\
\hline & & LVE-orto & horizonte $B 2$ & & \\
\hline 5,0 & 2,89 & - & 0,25 & 2,41 & 83,39 \\
\hline \multirow[t]{2}{*}{6,5} & 2,89 & 4,16 & 0,33 & 6,16 & 87,37 \\
\hline & & PVA-varia & Eo Piracicaba & horizonte & $\mathrm{Ap}$ \\
\hline 5,8 & 10,49 & - & 0,52 & 8,70 & 82,94 \\
\hline 7,5 & 10,49 & 3,54 & 0,40 & 13,23 & 94,91 \\
\hline
\end{tabular}


Tabela 19 - Quantidade de $\mathrm{K}^{+}$trocável e adicionado a terra an tes da lixiviação, quantidade de $\mathrm{K}^{+}$lixiviado,apōs o pulso de $\mathrm{K}^{+}$, e retido na coluna de terra bem co mo a razão de potássio trocável (RPT).

\begin{tabular}{|c|c|c|c|c|c|c|}
\hline \multicolumn{3}{|c|}{ Antes da lixiviação } & \multicolumn{3}{|c|}{ Após lixiviação } & \multirow{3}{*}{$\mathrm{RPT}$} \\
\hline \multirow{2}{*}{$\begin{array}{c}\mathrm{pH} \\
\mathrm{da} \\
\text { terra }\end{array}$} & \multirow{2}{*}{$\frac{\mathrm{K}^{+}}{\text {trocầvel }}$} & $\begin{array}{c}\mathrm{K}^{+} \\
\text {adicionado }\end{array}$ & \multirow{2}{*}{$\begin{array}{c}\mathrm{K}^{+} \\
\text {lixiviado } \\
\text { mea } / 240 \mathrm{ml}\end{array}$} & \multicolumn{2}{|c|}{$\begin{array}{l}\mathrm{K}^{+*} \\
\text { retido }\end{array}$} & \\
\hline & & g TFSE- & & meq $/ 100 \mathrm{~g}$ & $\%$ & \\
\hline \multicolumn{7}{|c|}{ LVE-orto - horizonte Ap } \\
\hline 5,2 & 0,81 & 0,30 & 0,12 & 0,97 & 87,39 & 0,264 \\
\hline 6,5 & 0,81 & 0,30 & 0,10 & 0,88 & 79,28 & 0,118 \\
\hline \multicolumn{7}{|c|}{ LVE-orto - horizonte B2 } \\
\hline 5,0 & 0,29 & 0,30 & 0,053 & 0,49 & 83,05 & 0,203 \\
\hline 6,5 & 0,29 & 0,30 & 0,026 & 0,53 & 89,83 & 0,086 \\
\hline \multicolumn{7}{|c|}{$\underline{\text { PVA-variação Piracicaba - horizonte Ap }}$} \\
\hline 5,8 & 0,20 & 0,30 & 0,024 & 0,44 & 88,00 & 0,050 \\
\hline 7,5 & 0,20 & 0,30 & 0,020 & 0,46 & 92,00 & 0,035 \\
\hline
\end{tabular}

* Quantidade de $\mathrm{K}^{+}$que permaneceu nos solos apỏs terem sido percolados $440 \mathrm{ml}$, contados a partir do início da lixiviação. 
A quantidade de cálcio mais magnésio lixiviados dos horizontes Ap e B2 do LVE-orto $\mathrm{pH} \mathrm{5,2,} \mathrm{praticamente} \mathrm{foi} \mathrm{a}$ mesma, o que não ocorreu depois de ter sido corrigido o $\mathrm{pH}$ das amostras de terra, Neste caso, lixiviou mais câlcio e magné- sio do horizonte B2.. Quanto ao potảssio, a quantidade lixi viada do horizonte Ap foi sempre superior a do B2 (Tabela 19).

Com o aumento do $\mathrm{pH}$, a lixiviação do câlcio mais magnésio, em valores absolutos aumentou e a do potássio dimi nuiu, porém, percentualmente, houve maior retenção dos câtions no solo. Isto pode ser explicado pela maior quantidade de car gas negativas superficiais dos colóides, decorrentes do aumento do $\mathrm{pH}$.

A razão de potássio trocável (Tabela 19), diminuiu com o aumento do $\mathrm{pH}$, o que indica ter ocorrido nos solos, maior adsorção de cálcio mais magnésio em relação ao potássio. Este comportamento é semelhante ao observado no estudo do equi líbrio catiônico (item 4.2), estando de acordo com a literatura, isto é, com o aumento do $\mathrm{pH}$ ocorre aumento na densidade de carga superficial, e, consequentemente, os câtions divalentes são adsorvidos preferencialmente em relação aos monovalentes (BOLT, 1955).

Com a finalidade de mostrar que é possível esti mar a RAP do percolado em função da RPT e constante de Gapon, 
foi feito uma correlação entre as RAP determinada e estimada. A determinada corresponde a um valor médio da RAP de cada volume de percolado coletado apôs o pulso, e a RAP estimada $\vec{e}$ obtida dividindo-se a razão dos cátions trocāveis (K/Ca + Mg) existentes nos solos, no momento em que estes receberam o pul so, pela constante de Gapon. Os valores utilizados desta cons tante foram aqueles obtidos no estudo do equilíbrio entre K-Ca (item 4.2). A Figura 12 mostra que hả uma boa correlação entre as RAP determinada e estimada para as seis amostras de terra, sugerindo que é possível predizer o valor de RAP de uma solução, que percola numa coluna de terra, cujos valores de RPT e constante de Gapon são conhecidos.

A correlação entre a RAPe RPT, embora tenha si do significativa, seu coeficiente $\left(r=0,84^{*}\right)$ foi menor do que o da Figura 12, quando se considerou a constante de Gapon.

Vale ressaltar, que cada amostra de terra, dependendo do horizonte a que pertence e do seu $\mathrm{pH}$, apresenta uma determinada constante de Gapon e que esta influi na relação entre RAP e RPT dos solos e varia de acordo com a densida de de carga superficial. Desta maneira, pode-se dizer que a densidade de carga superficial influi na RAP dos solos. 
67.

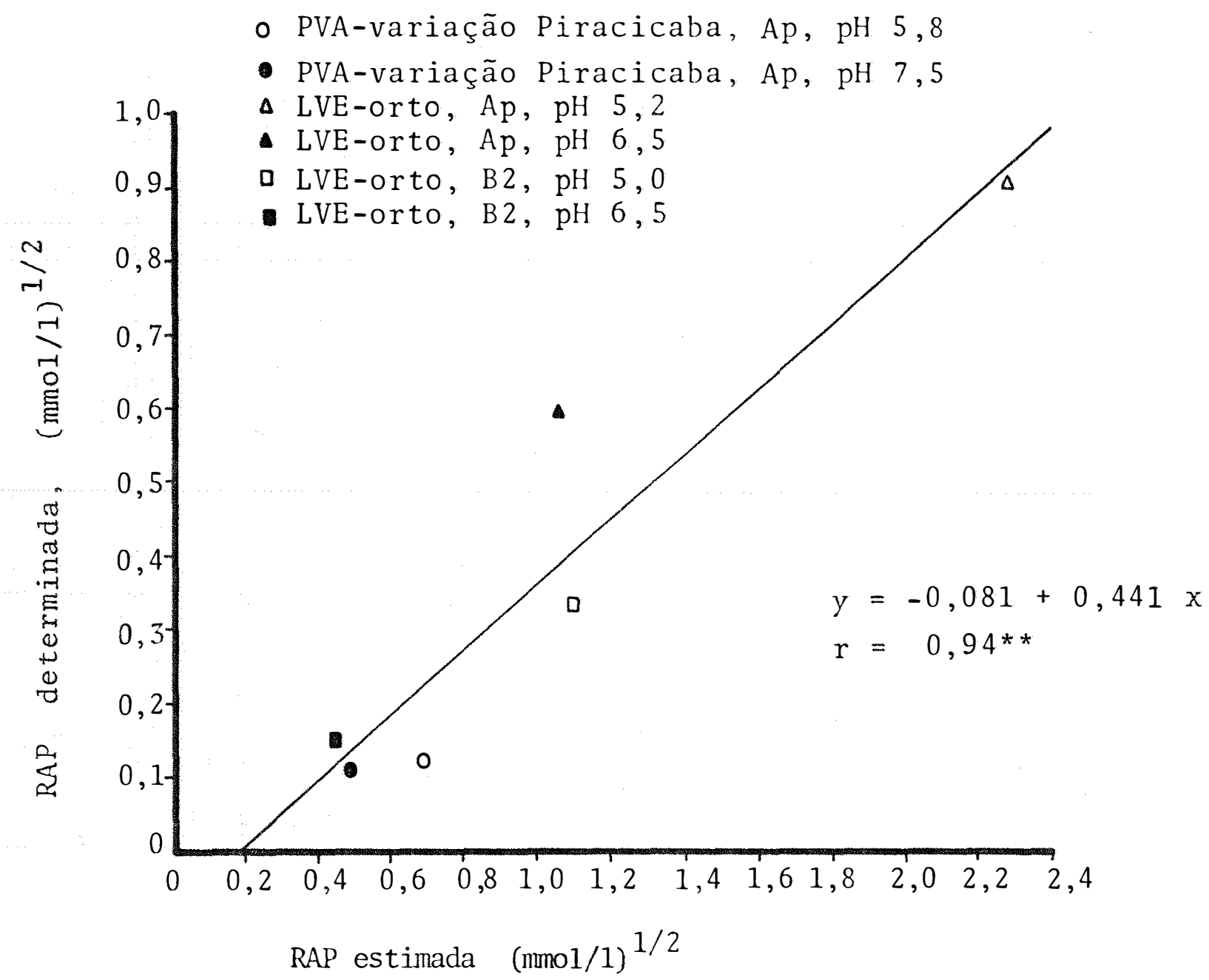

Figura 12 - Variação da razão de adsorção de potăssio (RAP) determinada em função da estimada. 


\subsection{Discussão geral}

o estudo do equilíbrio catiônico que ocorre nos solos, torna-se importante à medida em que è utilizado para resolver problemas präticos.

Conhecendo-se a constante de Gapon de um solo e a razão entre os cătions trocâveis, pode-se estimar a razão dos câtions na solução do solo. Com esta informação, torna-se pos sível uma recomendação de adubação potâssica mais adequada visando uma menor perda do adubo por lixiviação.

Quando uma cultura é instalada em dois solos com diferentes densidades de carga superficial, mas que possuem por centagens iguais de saturação em potássio e por isso recebem a mesma adubação potássica, ela pode responder a adubação apenas em um dos solos. Não deixando de considerar outros fatores que influenciam nesta resposta, pode-se dizer que, provavelmente, os solos tenham diferentes constantes de Gapon e que isto este ja interferindo na resposta da cultura. O solo onde não ocorreu resposta da cultura à adubação, provavelmente, apresenta maior constante de Gapon, o que faz com que o potảssio seja mais fortemente adsorvido pelo solo. Neste caso, porëm, para que houvesse resposta da cultura, a adubação deveria ter sido maior. 
Outra informação que deve ser considerada na prática é que, a densidade de carga superficial dos solos varia em função do pH. Assim, quando se faz calagem, a densida de de carga superficial dos solos aumenta e, consequentemente, sua CTC. Em solos com pH em torno de 5,0, cuja densidade de carga superficial e CTC efetiva, geralmente são baixas, a dis ponibilidade do potássio também o é, isto porque o cátion fica fortemente retido pelos colóides dos solos. Desta maneira, adubação potássica nestes solos, após a calagem, será, com certeza, diferente daquela que deveria ser feita antes da cor reção do pH, pois, a disponibilidade do elemento aumenta conforme o aumento da densidade de carga superficial.

Portanto, sugere-se que futuros experimentos, utilizando-se plantas, sejam conduzidos, levando-se em consideração as informações obtidas neste trabalho. 
70.

\section{CONCLUSOES}

De acordo com os resultados obtidos e sua inter pretação, foram possíveis as seguintes conclusães:

A densidade de carga superficial dos solos Podzö1ico Vermelho Amarelo-variaçôes Laras e Piracicaba, Latossol Vermelho Escuro-orto, Latossol Roxo e Terra Roxa Estruturada, aumenta com a elevação do $\mathrm{pH}$.

No equilíbrio catiónico, quando se considera po tássio trocando câlcio, os valores da constante de Gapon diminuem com o aumento da densidade de carga superficial dos solos.

Para um mesmo valor de razão de adsorção de potássio (RAP), a medida em que a densidade de carga superficial dos solos aumenta ocorre um aumento da adsorção preferencial de cálcio pelos solos, em relação ao potássio. 
Na lixiviação de cätions, o valor mëdio das razões entre potássio e cálcio mais magnêsio (RAP) de cada volume de percolado coletado, varia proporcionalmente à razão destes mesmos cátions na forma trocāvel, sendo que a correlação entre eles ë melhor quando se toma em consideração a constante de Gapon. 
6. LITERATURA CITADA

AYRES, A.S. e H.H. HAGIHARA, 1953. Effect of the anion on the sorption of potassium by some humic and hydrol humic Latosols. Soil Sci. Baltimore, 75; 1-17.

BECKETT, P.H.T., 1965. The cation exchange equilibria of $\mathrm{Ca}$ and Mg. Soil Sci. Baltimore, 100: 118-23.

BITTENCOURT, V.C. e M. SAKAI, 1975. Lixiviação do K nativo de solos tropicais. BC-027. Centro de Energia Nuclear na Agri cultura (USP/CNEN). Piracicaba-SP. 21 p.

BOHN, H.L.; B.L. MCNEAL E G.A. O'CONNOR, 1979. SOil chemistry. New York, John wiley-Insterscience. 329 p.

BOLT, G.H., 1955. Ion adsorption by clays. Soil Sci. Balti more, 79: 267-276. 
BOLT, G.H.; M.E. SUMNER \& A. KAMPHORST, 1963. A study of the equilibria between three categories of potassium in an Illitic Soil. Proc. Soil Sci. Soc. Madison, 27: 294-299.

BORNEMISZA, E., 1982. Introduccion a 1a quimica de suelos. Washington, Secretaria General de la OEA, Departamento de Assuntos Científicos y Tecnolögicos. 74 p.

Bouyoucos, G.J., 1951. A recalibration of the hydrometer methods for making analysis of soils. Agron. J. Madison, 43: $434-438$.

BOWER, C.A., 1959. Cation-exchange equilibria in soils affected by sodium salts. Soil Sci. Baltimore, 88: 32-35.

BRADY, N.C., 1979. Natureza e propriedades dos solos. Rio de Janeiro, Livraria Freitas Bastos, $647 \mathrm{p}$.

BRASIl. Serv. Nac. de Pesq. Agronômicas. Comissão de Solos, 1960. Levantamento de Reconhecimento dos Solos do Estado de São Paulo. Ministërio da Agricultura, CNEPA. (Boletim 12). $634 \mathrm{p}$. 
BRAUNER, J.L. e J.R.B. GARCEZ, 1982. Lixiviação de potässio, cälcio e magnësio em solos do Rio Grande do Sul submetidos à calagem, avaliada em condiçōes de laboratörio. R. bras. Ci. Solo. Campinas, $\underline{6}:$ 89-93.

CARSON, C.D. e J.B. DIXON, 1972. Potassium selectivity in certain montmorillonitic soil clays. Proc. Soil Sci. Soc. Amer. Madison, 36: 838-843.

CATANI, R.A, e A.0. JACINTHO, 1974. Anälise química para. avaliar a fertilidade do solo. Piracicaba, ESALQ/USP. Boletim Técnico Científico n? $37,57 \mathrm{p}$.

CIHACEK, L.J. e J.M. BREMNER, 1979. A simplified ethylene gly col monoethyl ether procedure for assessment of soil surface area. J. Soil Sci. Soc. Amer. Madison, 43: 821-822.

COLEMAN, N.T. e A. MEHLICH, 1948. Some chemical properties of soils as related to their cation exchange - anion exchange ratios. Proc. Soil Sci. Soc. Amer. Madison, 13: 175-178.

DEFELIPO, B.V. e J.M. BRAGA, 1983. Influência da calagem e fon tes de potássio na adsorção de potássio em Latossolos de Mi nas Gerais. R.bras.Ci. Solo. Campinas, 7: 119-122. 
DOLCATER, D.L.; E.g. LOTSE; J.K. SYERS E M.L. JACKSON, 1968. Cation exchange selectivity of some clay-sized Minerals and soil materials. Proc.Soil Sci. Soc. Amer. Madison, 32: $795-799$.

EDMEADES, D.C., 1982. Effects of 1 ime on effective cation exchange capacity and exchangeable cations on a range of New Zealand soils. N.Z. Journal of Agricultural Research. Wellington, 25: 27-33.

ELSEEWI, A.A.; H.A. ELATTAR e A.M. DAOUD, 1977. Relationship between soluble and exchangeable sodium in some soils of the Nile delta: An examination of the SAR concept. Soil Sci. Baltimore, 124: 249-254.

ERIKSSON, E., 1952. Cation exchange equilibria in clay minerals. Soil Sci. Baltimore, 74: 103-113.

ESPINOZA, w. e A.E.G. dos REIS, 1982. Lixiviação de Ca, K e Mg em um Latossolo Vermelho-Escuro (LE) de Cerrados. I. Magnitu de e variabilidade do fenômeno na época chuvosa. Pesq. Agropecuāria bras. Brasilia, 17(2): 229-317. 
E.U.A. Soil Conservation Service. Soil Survey Staff, 1975. Soil Taxonomy. A Basic System of Soil Classification for Making and Interpreting Soil Surveys. Washington, D.C. , USDA, $754 \mathrm{p}$.

FASSBENDER, H.W., 1980. Quimica de Suelos. San Josê, Institu to Interamericano de Ciências Agrícolas. 398 p.

GALINDO, G.G. e F.T. BINGHAM, 1977. Homovalent and heterova lent cation exchange equilibria in soils variable surface charge. J.Soil Sci. Soc. Am. Madison, 41: 883-886.

GHEYI, H.R. e R. VAN BLADEL, 1976. Calcium-sodium exchange in some calcareous soils and a montmorillonite clays as compared with predictions based on double layer theory. Geoderma. Amsterdam, 16(2): 159-169.

GILLMAN, G.P. e R.L. FOY, 1980. Increases in the cation exchan ge capacity of variable charge soils following superphosphate application, J. Soil Sci. Soc. Amer. Madison, 44: 934-938.

GOEDERT, W.J.; R.B. COREY I.K. SYERS, 1975. The effects on potassium equilibria in soils of Rio Grande do Sul, Brazil. Soil Sci. Baltimore, 120: 107-111. 
GROHMANN, F., 1977. Correlação entre superfície específica e outras propriedades de solos de São Paulo. R. bras. Ci. Solo. Campinas, $1(1): 9-12$.

HAVERAAEN, 0., 1978. Liming and fertilization of peat soil in pot experiment with spruce.Meldinger fra Norges tandbrukshøgskole 57(44). Apud: Soils and fertilizers, 1981. 44(6): 590 .

HOSSNER, L.R. Q.E.C. DOLL, 1970. Magnesium fertilization of potatoes as related to liming and potassium. Proc. Soil Sci. Soc. Am.. Madison, 34: 772-773.

HUINSAKER, U.E. e P.F. PRATT, 1971. Calcium-magnesium exchange equilibria in soils. Proc. Soil Sci.Soc.Amer. Madison, 35: $151-152$.

JACKSON, M.L., 1958. Soil Chemical Analysis. Englewood Cliff, Prentice-Hall, Inc. 498 p.

JENSEN, H.E. e K.L. BABCOCK, 1973. Cation-exchange equilibria on a Yolo Loam. Hilgardia. Berkeley, 노(16): 475-487.

KAMPRATH, E.J. e C.D. FOY, 1973. Lime-fertilizer plant inte ractions in acid soils. In: OLSOM, R.A. et alii. Fertilizer Technology and Use. Madison, Soil Science Society of America. p. 105-151. 
KIN30, T., 1980. Adição de sódio a solos da região tropical ümida: adsorção de $\mathrm{Na}^{+}$pelo solo e seu efeito na absorção de base pelas plantas. Piracicaba, ESALQ/USP, 111 p. (Tese de Livre-Docente).

MEKARU, T. e G. UEHARA, 1972. Anion adsorption in ferruginous tropical soils. Proc. Soil Sci. Soc. Amer. Madison, 36: $296-300$.

MENGEL, K. e E.A. KIRKBY, 1982. Principles of Plant Nutrition. 3: ed. Switzerland, International Potash Institute. Bern. $655 \mathrm{p}$.

MOHR, W., 1960, A influência da acidez sobre a fertilidade dos solos. In: Congresso Nacional de Conservação de Solos, 1 , Campinas. Anais. p. 62-75.

MORAIS, I.F.; A.L. PAGE $e$ L.J. LUND, 1976. The effect of pH, salt concentration, and nature of eletrolytes on the charge characteristics of Brazilian tropical soils. J. Soil Sci. Soc. Amer. Madison, 40: 521-527.

MORTLAND, M.M., 1954. Specific surface and its relationship to some physical and chemical properties of soils. Soil Sci. Baltimore, 78: 343-347. 
PRATT, P.F., 1961. Effect of $\mathrm{pH}$ on the cation-exchange capacity of surface soils. Proc. Soil Sci. Soc. Amer. Madison, 25: $96-98 \mathrm{p}$.

PRATT, P.F.; L.D. WHITTIG e B.L. GROVER, 1962. Effect of pH on the sodium-calcium exchange equilibria in soils. Proc. Soil Sci. Soc. Amer. Madison, 26: 227-230.

QUAGGIO, J.A.; A.R. DECHEN e B. van RAIJ, 1982. Efeito da aplí caçaõ de calcārio e gesso sobre a produção de amendoim e lí xiviação de bases no solo. R. bras. Ci. Solo. Campinas, $\underline{6}$ : $189-194$.

RAIJ, B. van, 1969. A capacidade de troca de cătions das frações orgânicas e mineral do solo. Bragantia. Campinas, 28: $85-112$.

RAIJ, B. van e M. PEECH, 1972. Eletrochemical properties of some Oxisols and Alfisols of the tropics. Proc. Soil Sci.Soc. Amer. Madison, 36: 587-593.

RAIJ, B. van, 1973. Determinação do ponto de carga zero em so1os. Bragantia. Campinas, 32: 337-347. 
RAIJ, B. van e O.A. CAMARGO, 1974. Influência das bases trocâa veis na lixiviação de potảssio em colunas de solos. In: Congresso Brasileiro de Oiência do Solo, 14. Santa Maria, 1973. Anais, Santa Maria, Sociedade Brasileira de Ciência do Solo, p. 263-268.

REEVE, G. e M.E. SUMNER, 1972. Ame1ioration of subsoil acidify in Natal Oxisols by leaching of surface applied amendments. Agrochemophisica. Pretoria, 4: 1-6.

RITCHEY, K.D.; J.E. SILVA e D.M.G. SOUZA, 1981. Lixiviação de cálcio e crescimento de raízes em solos de Cerrados. In: Congresso Brasileiro de Ciência do Solo, 18, Salvador, 1981. Programas e Resumos. p, 96.

RITCHEY, K.D., 1982. O potässio nos Oxissolos e Ultissolos dos Tröpicos Umidos. Piracicaba, Instituto Internacional da Potassa. 69 p. (Bo1etim Tëcnico, 7).

ROJAS, I.L. de e M.J.ADAMS, 1980. Efecto del cultivo sobre el puento de carga neta cero (PCNC) en tres suelos altamente in temperizados com aplicaciones de calcio y fosforo. Agronomia Tropical. Maracay, $\underline{30}(1$ a 6$): 29-54$. 
ROSOLEM, C.A. e J.R. MACHADO, 1984. Efeitos da calagem e gessagem na produção de algodão e na lixiviação de bases em dois Latossolos. R. bras. Ci. Solo. Campinas, 8: 103-109.

SALMON. R.C., 1964. Cation exchange reactions. J.Soil Sci. Oxford, 15: 273-283.

SCHALSCHA, E.B.; P.F. PRATT; T. KINJO e J. AMAR A, 1972. Effect of phosphate salts as saturating solutions in cation-exchange capacity determinations. Proc. Soil Sci. Soc. Amer. Madison, 36: 912-914.

SCHALSCHA, E.B.; P.F. PRATT E D. SOTO, 1974. Effect of phospha te adsorption on the cation exchange capacity of volcanic ash soil. Proc. Soil Sci. Soc. Amer. Madison, 38: 539-540.

SCHALSCHA, E.B.; P.F. PRATT e L. de ANDRADE, 1975. Potassiumclacium exchange equilibria in volcanic-Ash soils. Proc. Sci. Soc. Amer. Madison, 39: 1069-1072.

SOUZA, D.M.G.; K.D. RITCHEY; E. LOBATO \& W.J. GOEDERT, 1979. Potảssio em solo de Cerrado. II. Balanço no solo. R. bras. Ci. Solo. Campinas, 3: 33-36. 
SPOSITO, G. e S.V. MATTIGOD, 1977. On the chemical foundation of the sodium adsorption ratio. J. Soil Sci. Soc. Amer. Ma dison, 41: 323-239.

LEHARA, G. e G.P. GILLMAN, 1980. Charge characteristics of soils with variable e permanent charge minerals: I. Theory. J. Soil Sci. Soc. Amer. Madison, 44: 250-252.

VARBANOVA, Z. e B.W. BACHE, 1975. The effects of pH on adsorp tion and desorption of potassium in a granitic soil. J. Sci. Fd. Agric. London, 26: 855-860.

VASCONCELLOS, C.A., 1976. Equilíbrio iônico e capacidade de troca de cátions, de alguns solos, em função do pH e dos teores de cálcio e magnésio. Piracicaba, ESALQ/USP. $112 \mathrm{p}$. (Tese de Doutoramento).

WALKLEY, A. e I.A. BLACK, 1934. An examination of the Degtja reff method for determining soil organic matter and a propo sed modification of the chromic acid titration method. Soil Sci. Baltimore, 37: 29-38.

WANN, S.S. e G. UEHARA, 1978. Surface change manipulation in constant surface potencial soil colloids: II. Effect on solu te transport. Proc. Soil Sci. Soc. Amer. Madison, 42: 886888 . 
WIKLANDER, L., 1960. Influence of liming on adsorption and de sorption of cation in soils. $7^{\text {th. Intern. Congress of Soil }}$. Science. Madison, USA, p. 283-291.

WIKLANDER, L., 1964. Cation and anion exchange phenomena. In: BEAR, F.E., Ed. Chemistry of the soil. New York, Reinholds Publishing Co., p. 163-205.

YORK Ir., E.T.; R. BRADFIELD e M. PEECH, 1953. Calcium-potassium interactions in soil and plants. I. Lime-induced potas sium fixation in mardin silt loams. Soil Sci., Baltimore, 76: $379-387$.

ZAWARTKA, L., 1978. Leaching of minerals from various brown soils. III. Calcium and chlorine. Zeszyty Naukowe Akademii Rolniczo - Techiniczney Wolsztynie, Rolnictwo n: 138 (25): 3-12. Apud: Soils and fertilizers, 1979, 42(12): 769 . 